\title{
Characteristics of rainfall events in regional climate model simulations for the Czech Republic
}

\author{
Vojtěch Svoboda $^{1,2}$, Martin Hanel ${ }^{1,3}$, Petr Máca ${ }^{1}$, and Jan Kyselý ${ }^{1,2}$ \\ ${ }^{1}$ Faculty of Environmental Sciences, Czech University of Life Sciences Prague, Kamýcká 129, Praha 6 - Suchdol, \\ 165 21, Czech Republic \\ ${ }^{2}$ Institute of Atmospheric Physics, Czech Academy of Sciences, Boční II 1401, Praha 4 - Spořilov, 141 31, Czech Republic \\ ${ }^{3}$ T. G. Masaryk Water Research Institute, Podbabská 2582/30, Praha 6 - Dejvice, 160 00, Czech Republic \\ Correspondence to: Vojtěch Svoboda (vsvoboda@fzp.czu.cz)
}

Received: 3 June 2016 - Discussion started: 21 June 2016

Revised: 26 January 2017 - Accepted: 28 January 2017 - Published: 15 February 2017

\begin{abstract}
Characteristics of rainfall events in an ensemble of 23 regional climate model (RCM) simulations are evaluated against observed data in the Czech Republic for the period 1981-2000. Individual rainfall events are identified using the concept of minimum inter-event time (MIT) and only heavy events ( $15 \%$ of events with the largest event depths) during the warm season (May-September) are considered. Inasmuch as an RCM grid box represents a spatial average, the effects of areal averaging of rainfall data on characteristics of events are investigated using the observed data. Rainfall events from the RCM simulations are then compared to those from the at-site and area-average observations. Simulated number of heavy events and seasonal total precipitation due to heavy events are on average represented relatively well despite the higher spatial variation compared to observations. RCM-simulated event depths are comparable to the area-average observations, while event durations are overestimated and other characteristics related to rainfall intensity are significantly underestimated. The differences between RCM-simulated and at-site observed rainfall event characteristics are in general dominated by the biases of the climate models rather than the areal-averaging effect. Most of the rainfall event characteristics in the majority of the RCM simulations show a similar altitude-dependence pattern as in the observed data. The number of heavy events and seasonal total precipitation due to heavy events increase with altitude, and this dependence is captured better by the RCM simulations with higher spatial resolution.
\end{abstract}

\section{Introduction}

Potential changes in characteristics of precipitation due to climate change may have significant societal impacts. Several studies have reported significant changes in daily precipitation extremes in observed data (e.g. Alexander et al., 2006; Trenberth, 2011; Westra et al., 2014) as well as in climate model projections (e.g. Kyselý et al., 2011; Hanel and Buishand, 2012; Madsen et al., 2014). It is argued that the intensity of short-duration extreme events in particular might increase more in future climate due to dynamical feedbacks (Lenderink and van Meijgaard, 2008; Berg and Haerter, 2013; Millán, 2014).

The climate change scenarios for precipitation are frequently based on simulations of regional climate models (RCMs). Even as the majority of RCM simulations available are conducted in resolution coarser than $10 \mathrm{~km}$, the convective processes associated with heavy rainfall actually develop at much finer scales ( $<4 \mathrm{~km}$; Prein et al., 2015). RCMs usually rely, therefore, on convection parameterization schemes, even though these are known sources of significant uncertainties and errors (Brockhaus et al., 2008; Hohenegger et al., 2008; Kendon et al., 2012). That is especially the case for the simulated sub-daily precipitation (Westra et al., 2014).

Many studies of precipitation extremes across Europe examine daily data from RCM simulations (e.g. Fowler and Ekström, 2009; Herrera et al., 2010; Hanel and Buishand, 2011, 2012; Rajczak et al., 2013; Bartholy et al., 2015; Danandeh Mehr and Kahya, 2016). Although growing attention has been given to studies at sub-daily timescales in recent years, 
the complexity of physical processes related to sub-daily extremes (Stocker et al., 2013; Siler and Roe, 2014) and their simplification within climate model parameterizations make assessment of simulated sub-daily precipitation challenging, particularly since its validation is impaired by the lack of long and high-quality observed rainfall data series at hourly or sub-hourly timescales with sufficient spatial coverage allowing for comparison to simulated (spatial average) rainfall (Westra et al., 2014).

The existing studies on RCM-simulated sub-daily rainfall are typically looking at precipitation maxima in a number of temporal aggregations (Hanel and Buishand, 2010; Gregersen et al., 2013; Sørup et al., 2017), dependence of RCM performance on its resolution (Prein et al., 2016; Sunyer et al., 2017), diurnal cycle of simulated hourly precipitation (Prein et al., 2015 and references therein) or scaling of precipitation extremes with temperature (Lenderink and van Meijgaard, 2008; Ban et al., 2015; Martínková and Hanel, 2016). Studies looking in detail into individual rainfall event characteristics in RCM simulations are missing despite the fact that such characteristics of heavy rainfall events as event depth, duration, or intensity are relevant for urban hydrology (e.g. Einfalt et al., 1998; Barbosa et al., 2012; Willems et al., 2012) and determine characteristics of various hydrological processes as overland flow generation and shape of the resulting hydrograph (Singh, 1997), soil moisture dynamics (Wang et al., 2008; He et al., 2012), infiltration (Ran et al., 2012), rainfall erosion (Wischmeier and Smith, 1978), evaporation (Dunkerley, 2008a), storm sewer flow rates and direct runoff (Schilling, 1991; Giulianelli et al., 2006). Therefore considering these individual rainfall event characteristics is important also in RCM evaluation studies, which has been highlighted already by, for example, Westra et al. (2014), who suggested (among other things) to focus on (spatial structure and) temporal evolution of rainfall events and their timing and intermittency.

The purpose of this study is to assess heavy rainfall event characteristics (considering $15 \%$ of events with the largest event depths) in an ensemble of RCM simulations using hourly data conducted within the ENSEMBLES (van der Linden and Mitchell, 2009) and EURO-CORDEX (Jacob et al., 2014) projects. Assessments of simulated precipitation at sub-daily timescales often face problems with data availability. Sub-daily RCM simulations are in general not easily available and relevant (sub-daily) observational products allowing for direct comparison between RCMs (representing spatial averages) and observations (point measurements) are lacking. Deflation of maxima due to spatial averaging is well recognized and expressed by so-called areal reduction factors (Svensson and Jones, 2010). Clearly the spatial averaging also affects the rainfall event characteristics, however, any quantitative assessment is lacking in the literature. The methodology allowing for comparison of RCM-simulated rainfall event (spatial) characteristics to (point) observations is presented in the study when the simulated rainfall events are compared to observations in the Czech Republic for the period 1981-2000.

The paper is organized as follows: Section 2 describes the study area, as well as the observed and RCM-simulated data. Section 3 presents the definition of rainfall events, the event characteristics considered, and the approaches for assessing areal-averaging effects and biases in the RCM simulations. Results concerning the effects from areal averaging on rainfall events and evaluation of RCM-simulated rainfall event characteristics are presented in Sect. 4 and discussed in Sect. 5. Key findings are summarized in Sect. 6.

\section{Study area and data}

\subsection{Study area}

Rainfall event characteristics are analysed for the Czech Republic $\left(78800 \mathrm{~km}^{2}\right)$, located in central Europe (Fig. 1a). Orography of the country varies considerably. As can be seen in Fig. 1b, approximately two-thirds of the area is situated at altitudes below $500 \mathrm{~m}$ above sea level (a.s.l.), even as several mountain ranges exceed $1200 \mathrm{~m}$ a.s.l.

Average annual precipitation totals for the period 19612000 vary from about $420 \mathrm{~mm}$ in the central-western part of the country to more than $1200 \mathrm{~mm}$ in the mountains. Mean annual precipitation for the Czech Republic is about $670 \mathrm{~mm}$, with a single maximum occurring at most stations in June and July (Tolasz, 2007). If averaged across the Czech Republic, almost two-thirds of the annual precipitation falls in the warm half of the year. Rainfall events during the warm period (April-September) are usually of shorter duration and greater intensity. Rainfall or snowfall events during the cold half of the year (October-March), meanwhile, are mainly characterized by lower intensities and longer durations, and these are associated with passing frontal systems and pressure lows (Tolasz, 2007).

\subsection{Observed precipitation data}

In the present study, we used hourly precipitation data provided by the Czech Hydrometeorological Institute. The original data in $10 \mathrm{~min}$ resolution are based on digitized pluviograph records (from float-type self-recording pluviographs with interception area of $250 \mathrm{~cm}^{2}$ ) and were quality checked by Květoň et al. (2004), who identified and reconstructed damaged or missing pluviograph records while considering many sources of rainfall information. Hanel and Máca (2014) had further assessed the quality of the reconstructed data set by comparing daily precipitation depths aggregated from 10 min data with daily precipitation depths from standard ombrometers. They had considered data for a day unreliable when the difference exceeded $1.5 \mathrm{~mm}$ for daily precipitation totals below $15 \mathrm{~mm}$ or $10 \%$ for daily precipitation totals above $15 \mathrm{~mm}$. The years with the fraction of unreliable 
(a)

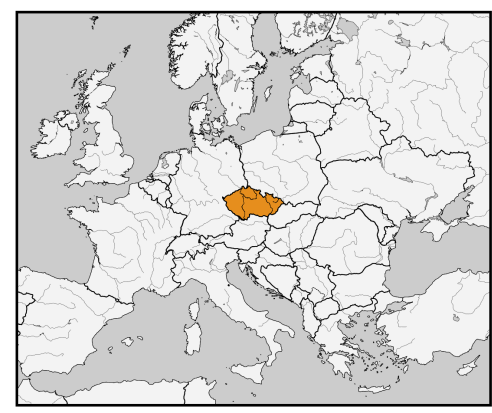

(b)

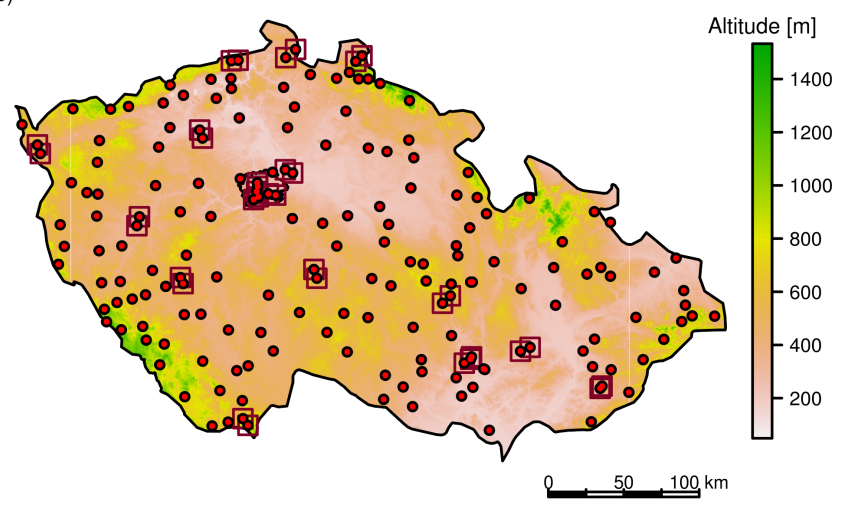

Figure 1. (a) Location of the Czech Republic in central Europe. (b) Stations (dots) used for assessing the areal-averaging effect and evaluating the RCM simulations. Rectangles show considered (36) square neighbourhoods for assessing the areal-averaging effect for $12.5 \mathrm{~km}$ resolution. Altitude is indicated by colour.

records larger than $10 \%$ were excluded from the data set. These same criteria were applied in the present study.

Given the unreliability of the pluviograph records in the winter period (Květoň et al., 2004), when large part of the precipitation falls as snow, only records from May to September have been considered. This period is hereinafter referred to as the "season". Only stations with at least 10 years of reliable data were used for the comparison of RCM-simulated and observed rainfall event characteristics in the validation period 1981-2000. The validation period was set to just 20 years in order to maximize overlap of the available RCM simulations (Sect. 2.3) and observed data. In total, 154 stations (with density of one station per $512 \mathrm{~km}^{2}$ ) fulfilled this condition. More than 15 years of reliable data were available for 60 stations.

In order to increase the number of stations available for spatial averaging, a longer period (1961-2009) was considered for analysing the areal-averaging effects. This resulted in making 26 additional stations available (each of which has records shorter than 10 years or ending before 1981). Figure $1 \mathrm{~b}$ shows all 180 stations from the data set, the density of which came to approximately one station per $438 \mathrm{~km}^{2}$.

Moreover, we examined the influence of the number of stations considered in the areal averaging using a dense rain gauge network for Prague (22 stations within $500 \mathrm{~km}^{2}$ ). Hourly precipitation data for the period 2002-2011 were provided by Pražská vodohospodářská společnost a.s., administrator of the Prague water management property.

\subsection{RCM simulations}

An ensemble of 23 RCM simulations was examined (see Table 1 for an overview). Six RCMs were driven by 14 global climate models (GCMs) to produce 19 simulations in total. Two RCMs (with a total of four runs) were also driven by ERA-40 (Uppala et al., 2005) or ERA-Interim (Dee et al., 2011) reanalysis.
The RCMs' outputs are available on a rotated latitudelongitude grid with horizontal resolutions ranging from 12.5 to $50 \mathrm{~km}$. Only the CLM simulation is on a regular grid. From each RCM simulation only grid boxes covering the area of the Czech Republic (i.e. 52-607 grid boxes for different resolutions and RCMs) were selected. Time resolution in which most RCM simulations were available was $1 \mathrm{~h}$ (the last column in Table 1), exceptions are the RCA4 simulations, which were aggregated to match the temporal resolution of the other RCMs.

The HIRHAM5, HadRM3, and RACMO2 simulations were conducted within the ENSEMBLES project (van der Linden and Mitchell, 2009), while the RCA4 and RACMO22E simulations were within the EURO-CORDEX project (Jacob et al., 2014). All RCM simulations are historical (forced by historical greenhouse gas concentrations, land use, solar forcing etc.), i.e. no emission/concentration scenario was considered. The forcings may be slightly different for the ENSEMBLES and CORDEX models.

Two of the HadRM3 simulations were driven by the GCM versions with perturbed physics parameterizations (Collins et al., 2006). HadCM3Q0 is an unperturbed model run, HadCM3Q3 is a version with a low sensitivity to external forcing (i.e. unit change in external forcing leads to a relatively small increase in global temperature), and HadCM3Q16 includes perturbations resulting in high sensitivity to external forcing. The perturbations in the HadRM3 RCM correspond to those in the HadCM3 GCM.

\section{Methods}

This section defines rainfall events in the observed and RCMsimulated data (Sect. 3.1) and describes those event characteristics considered (Sect. 3.2). Inasmuch as the RCM data represent areal averages rather than point values, the methods for assessing the effect on event characteristics from areal 
Table 1. RCM simulations analysed.

\begin{tabular}{|c|c|c|c|c|}
\hline \multicolumn{5}{|c|}{ RCM (reference) - Institution producing the model output } \\
\hline Abbreviation & Driven by & Horizontal resolution & Number of grid boxes & Time resolution \\
\hline \multicolumn{5}{|c|}{ CLM 2.4.11 (Böhm et al., 2006; Lautenschlager et al., 2009) - Max Planck Institute for Meteorology (MPI), Germany } \\
\hline CLM & ECHAM5/MPIOM & $22 \mathrm{~km}\left(0.2^{\circ}\right)$ & 301 & $1 \mathrm{~h}$ \\
\hline \multicolumn{5}{|c|}{ HadRM3.0 (Collins et al., 2011) - Met Office Hadley Centre (MOHC), UK } \\
\hline HadRM3Q0_ERA40 & ERA-40 & $25 \mathrm{~km}\left(0.22^{\circ}\right)$ & 173 & $1 \mathrm{~h}$ \\
\hline HadRM3Q3_ERA40 & ERA-40 & & & \\
\hline HadRM3Q16_ERA40 & ERA-40 & & & \\
\hline HadRM3Q0_HadCM3 & HadCM3Q0 & & & \\
\hline HadRM3Q3_HadCM3 & HadCM3Q3 & & & \\
\hline HadRM3Q16_HadCM3 & HadCM3Q16 & & & \\
\hline \multicolumn{5}{|c|}{ HIRHAM5 (Christensen et al., 2007) - Danish Meteorological Institute (DMI) } \\
\hline H5_ARPEGE & ARPEGE & $25 \mathrm{~km}\left(0.22^{\circ}\right)$ & 173 & $1 \mathrm{~h}$ \\
\hline H5_BCM & $\mathrm{BCM}$ & & & \\
\hline H5_ECHAM5 & ECHAM5-r3 & & & \\
\hline \multicolumn{5}{|c|}{ RACMO2.1 (van Meijgaard et al., 2008) - Royal Netherlands Meteorological Institute (KNMI) } \\
\hline RACMO2_ECHAM5 & ECHAM5-r3 & $25 \mathrm{~km}\left(0.22^{\circ}\right)$ & 173 & $1 \mathrm{~h}$ \\
\hline RACMO2_MIROC & MIROC3.2 & & & \\
\hline \multicolumn{5}{|c|}{ RACMO22E (van Meijgaard et al., 2012) - Royal Netherlands Meteorological Institute (KNMI) } \\
\hline RACMO22E & ICHEC-EC-EARTH & $12.5 \mathrm{~km}\left(0.11^{\circ}\right)$ & 607 & $1 \mathrm{~h}$ \\
\hline \multicolumn{5}{|c|}{ RCA4.0 (Kupiainen et al., 2011; Samuelsson et al., 2011) - Swedish Meteorological and Hydrological Institute (SMHI) } \\
\hline RCA4_ERAINT & ERA-Interim & $50 \mathrm{~km}\left(0.44^{\circ}\right)$ & 52 & $20 \mathrm{~min}$ \\
\hline RCA4_CanESM2 & CCCma-CanESM2 & & & \\
\hline RCA4_CM5A-MR & IPSL-CM5A-MR & & & $18 \mathrm{~min}$ \\
\hline RCA4_CNRM-CM5 & CNRM-CM5 & & & \\
\hline RCA4_EC-EARTH & ICHEC-EC-EARTH & & & \\
\hline RCA4_ESM2M & NOAA-GFDL-ESM2M & & & \\
\hline RCA4_ESM-LR & MPI-ESM-LR & & & \\
\hline RCA4_HadGEM2-ES & MOHC-HadGEM2-ES & & & \\
\hline RCA4_MIROC5 & MIROC5 & & & \\
\hline RCA4_NorESM1-M & NCC-NorESM1-M & & & \\
\hline
\end{tabular}

averaging of rainfall data are further described in Sect. 3.3. Finally, approaches taken in evaluating simulated rainfall events are presented in Sect. 3.4.

\subsection{Rainfall event definition}

Several methods exist for defining individual rainfall events (e.g. Peters and Christensen, 2006; Ignaccolo and Michele, 2010; Gaál et al., 2014). One approach frequently used involves the concept of minimum inter-event time (MIT), which defines events on the basis of a minimum time interval - reached or exceeded - between two individual events (Dunkerley, 2008b). The value of MIT should be selected so that the rainfall events are independent. A simple approach for defining independent rainfall events was presented by Restrepo-Posada and Eagleson (1982).
The value of MIT considerably influences rainfall event characteristics (Dunkerley, 2008b). For instance, for the observed sub-daily precipitation in the Czech Republic, Hanel and Máca (2014) reported a $40 \%$ decrease in event rainfall rate and more than 10-fold increase in event depth and duration with increasing MIT from $30 \mathrm{~min}$ to $24 \mathrm{~h}$. As a consequence, in order to provide comparable rainfall event characteristics, MIT should not vary among RCM simulations (and observed data). Therefore, a $6 \mathrm{~h}$ MIT was used for deriving rainfall events throughout this study. It should be noted that although this value is lower than the optimal MITs estimated for the Czech Republic by Hanel and Máca (2014), it is one of the most frequently used (Dunkerley, 2008b). For instance, $6 \mathrm{~h}$ MIT is applied for the identification of erosive 
rainfall events in the Universal Soil Loss Equation (USLE; Wischmeier and Smith, 1978).

Using the MIT concept for determination of individual events requires choice of the wet-hour threshold (i.e. precipitation amount below which the hour is considered dry). For the observed data, the choice often follows naturally from rain gauge precision leading frequently to wet-hour threshold of $0.1 \mathrm{~mm} \mathrm{~h}^{-1}$ (Dunkerley, 2015). In the case of RCM simulations, very small amounts of rainfall are simulated for most of the intervals (due to drizzling effect) and the smallest non-zero precipitation value, when used as the wet-hour threshold, would lead to excessively long events. Therefore, $0.1 \mathrm{mmh}^{-1}$ was considered as the wet-hour threshold for the observed data as well as the RCM simulations in our study. The same wet-hour threshold had been applied also for RCM simulations previously (e.g. Willems and Vrac, 2011; Kendon et al., 2014; Sunyer et al., 2017).

Our attention is aimed only at events potentially causing soil erosion or flooding (denoted heavy rainfall events further). The identification of such events was based on one of the criteria used in USLE, i.e. considering only those events with total depth larger than $12.7 \mathrm{~mm}$ (Wischmeier and Smith, 1978). For the observed precipitation this leads to selection of $\approx 15 \%$ of events with the largest event depths. The same fraction of events according to event depth was considered as heavy rainfall events in each RCM simulation. Note that we preferred to determine the simulated heavy rainfall events as a fraction of events $(\approx 15 \%$ with largest event depths) rather than as events with depth above a fixed threshold $(12.7 \mathrm{~mm})$, since because of inherent bias in RCM simulations there might be too many or too few (even none) events exceeding this threshold.

\subsection{Rainfall event characteristics}

We focused on the following basic characteristics of heavy rainfall events:

- event depth $D(\mathrm{~mm})$;

- event duration $T(\mathrm{~h})$;

- event mean rainfall rate $R\left(\mathrm{~mm} \mathrm{~h}^{-1}\right)$ :

$$
R=\frac{D}{T}
$$

- maximum 60 min rainfall intensity during an event $I_{60}$ $\left(\mathrm{mmh}^{-1}\right)$.

As our definition of a rainfall event is in general consistent with the USLE methodology, we consider also indicators of rainfall event erosivity:
- event rainfall energy $E\left(\mathrm{MJha}^{-1}\right)$ (Brown and Foster, 1987):

$E=\sum_{t=1}^{T} 0.29 d_{t}\left[1-0.72 \exp \left(-0.05 d_{t}\right)\right]$

where $d_{t}$ is rainfall volume during hour $t$, and

- event rainfall erosivity index $\mathrm{EI}_{60}\left(\mathrm{MJ} \mathrm{mm} \mathrm{ha}^{-1} \mathrm{~h}^{-1}\right)$ :

$$
\mathrm{EI}_{60}=E \times I_{60} .
$$

Note that in the USLE methodology, maximum $30 \mathrm{~min}$ rainfall intensity is used in Eq. (3). Due to the temporal resolution of RCM-simulated data in this study, we instead consider maximum 60 min rainfall intensity during an event $\left(I_{60}\right)$. The $E$ and $\mathrm{EI}_{60}$ indices are assessed here not in order to quantify soil loss but rather as indicators of the erosive potential of a rainfall event.

In addition to the aforementioned rainfall event characteristics, we analysed also the following seasonal (MaySeptember) characteristics:

- number of heavy rainfall events per season $N_{\text {se }}(-)$, and

- seasonal total precipitation due to heavy rainfall events $S_{\text {se }}(\mathrm{mm})$.

\subsection{Areal averaging of rainfall data}

Areal averaging of rainfall data can significantly affect such characteristics of rainfall events as depth (Svensson and Jones, 2010) or intensity (Eggert et al., 2015). Because an RCM grid box represents a spatial average, RCM simulations cannot be compared directly to at-site observations. Therefore, various gridded data sets are used for validation of RCM data (e.g. the E-OBS data set for Europe; Haylock et al., 2008). Unfortunately, the gridded data sets available are limited to daily or longer temporal resolution and cannot be used for validation of sub-daily RCM simulations. Therefore, analogously to the well-established areal reduction factors describing the decrease in rainfall/runoff maxima with increasing averaging area (e.g. Svensson and Jones, 2010), we quantified the effect that the areal averaging of rainfall data has on the rainfall event characteristics. This quantification was based on comparison of rainfall event characteristics derived for observed at-site data (further at-site characteristics) to those derived for area-average data (further areaaverage characteristics) with averaging area corresponding to the resolution of RCM simulations. Obviously we were able to calculate the area-average characteristics only at locations with dense station network.

The whole procedure can be summarized as follows: 
1. Square regions with area corresponding to the considered resolutions $(12.5,25$, and $50 \mathrm{~km})$ were defined around each station (the regions are further referred to as "neighbourhoods"). Each neighbourhood thus included one (the central) or more stations. Neighbourhoods including only one station were excluded from the analysis. This resulted in 36 neighbourhoods for the $12.5 \mathrm{~km}$ resolution (Fig. 1b), 118 for the $25 \mathrm{~km}$, and 180 for the $50 \mathrm{~km}$ resolution. The average number of stations included in the neighbourhoods was 2.25 for the $12.5 \mathrm{~km}, 2.90$ for the $25 \mathrm{~km}$, and 6.04 for the $50 \mathrm{~km}$ resolution.

2. Time series of areal average rainfall were calculated for each neighbourhood by averaging the data from included stations (for periods where station data sets overlapped). Rainfall events were determined and the rainfall event characteristics calculated for this areal average as well as at-site for the central station.

3. To quantify the difference between the area-average and at-site characteristics at each neighbourhood, we evaluated the following indices describing the differences in mean as well as in the whole distribution of rainfall event characteristics:

a. Ratio of mean areal to mean at-site (event and seasonal) characteristics. This ratio is further denoted $\mathrm{rt}_{\mathrm{m}}$.

b. Ratio of the $p$ th quantiles of areal event characteristics to the $p$ th quantiles of at-site event characteristics with $p=0.05,0.1, \ldots, 0.95$. This ratio is referred to as quantile ratio $\mathrm{rt}_{p}$.

c. Ratio of frequencies of corresponding bins of the histograms of areal and at-site event characteristics, further denoted as histogram ratio $\mathrm{rt}_{\mathrm{f}}$.

\subsection{Evaluation of RCM-simulated characteristics of rainfall events}

The RCM-simulated event characteristics (representing areal averages) were compared to the observed at-site characteristics considering the same indices as described in point 3 in Sect. 3.3 but replacing the observed areal average (event and seasonal) characteristics with the simulated characteristics for individual RCM grid boxes. To allow for assessment of grid boxes not including any station, the mean, $p$ th quantiles and bin frequencies for the at-site characteristics were averaged over the whole Czech Republic prior to the calculation of the ratios.

The ratios between the RCM-simulated and observed atsite rainfall characteristics represent the combination of the bias in the RCM simulation with the effect of areal averaging of rainfall data. Therefore, ratios for RCM-simulated characteristics were further compared to those for area-average observations.
Finally, we also evaluated the dependence of the RCMsimulated (event and seasonal) characteristics on altitude. A linear regression model of the dependence of the $p$ th quantile (for $p$ from 0.05 to 0.95 ) of the distribution of event characteristics on altitude was fitted for the RCM as well as the at-site data. Altitude dependence of rainfall event characteristics was then expressed as the change of a characteristic per $100 \mathrm{~m}$ altitude difference $\left(y_{p}\right)$ given by

$y_{p}=\frac{100 \beta_{p}+\alpha_{p}}{\alpha_{p}} \times 100(\%)$,

where $\beta_{p}$ is the slope coefficient and $\alpha_{p}$ is the intercept for the linear regression between the $p$ th quantile of the event characteristics and altitude. Moreover, the values of the estimated slope coefficient $(\beta)$ were analysed for the seasonal characteristics.

\section{Results}

This section presents findings related to areal averaging of rainfall data (Sect. 4.1). Further, the RCM-simulated rainfall event characteristics are evaluated with respect to the observed data for the validation period (1981-2000) using ratios of mean characteristics $\left(\mathrm{rt}_{\mathrm{m}}\right.$; Sect. 4.2), quantile ratios $\left(\mathrm{rt}_{p}\right.$; Sect. 4.3), and histogram ratios ( $\mathrm{rt}_{\mathrm{f}}$; Sect. 4.4). Altitude dependence of event characteristics considering the RCM simulations and at-site observations is assessed in Sect. 4.5.

\subsection{Effects of areal averaging in the observed data}

The number of heavy rainfall events $\left(N_{\mathrm{se}}\right)$ in area-average observations is approximately 1.4-2 events per season (i.e. ca. $26 \%$ ) higher than that for the at-site data for all considered spatial resolutions (Table 2, top four rows). Minimum event depth defining the top $15 \%$ of events (the heavy rainfall events) for area-average observations is lower than $12.7 \mathrm{~mm}$ (the value for the at-site data), and this results in smaller average event depths $(D)$ compared to those for the at-site observations. Smaller $D$ are compensated, however, by a higher number of events $\left(N_{\mathrm{se}}\right)$, and that leads to a good representation of seasonal totals due to heavy rainfall events.

Mean characteristics of rainfall events considered for the at-site and area-average observations are shown in the top four rows of Table 2. Observed area-average characteristics are in general lower than at-site characteristics: $D$ by 14$19 \%, T$ by $8-18 \%, R$ by $10-27 \%$, and $I_{60}$ by $23-39 \%$.

The quantile ratios $\mathrm{rt}_{p}$ are shown in Fig. 2. Because in general the spread of the quantile ratios is similar for the spatial resolutions considered (not shown), only the envelope of $\mathrm{rt}_{p}$ representing the maximum range between the 5th and 95th quantiles from all neighbourhoods for the three spatial resolutions is indicated by grey areas in Fig. 2 in addition to the mean quantile ratios for individual resolutions (given by lines). Area-average event depths $(D)$ are $\approx 10-20 \%$ smaller 
Table 2. Seasonal number of heavy rainfall events $\left(N_{\mathrm{se}}(-)\right)$, seasonal total precipitation due to heavy events $\left(S_{\text {se }}(\mathrm{mm})\right)$, and mean rainfall event characteristics (depth $D(\mathrm{~mm})$, duration $T(\mathrm{~h})$, mean rainfall rate $R\left(\mathrm{mmh}^{-1}\right)$, maximum 60 min intensity $I_{60}\left(\mathrm{~mm} \mathrm{~h}^{-1}\right)$, rainfall energy $E\left(\mathrm{MJ} \mathrm{ha}^{-1}\right)$, and rainfall erosivity index $\mathrm{EI}_{60}\left(\mathrm{MJ} \mathrm{mmha}^{-1} \mathrm{~h}^{-1}\right)$ ) for the 1981-2000 period in the observed data (top four rows) and the RCM simulations.

\begin{tabular}{|c|c|c|c|c|c|c|c|c|}
\hline Abbreviation & $N_{\mathrm{se}}$ & $S_{\mathrm{se}}$ & $D$ & $T$ & $R$ & $I_{60}$ & $E$ & $\mathrm{EI}_{60}$ \\
\hline At-site observations average & 7.62 & 194.7 & 25.0 & 19.7 & 2.37 & 9.38 & 3.66 & 48.75 \\
\hline \multicolumn{9}{|l|}{ Area-average observations } \\
\hline $12.5 \mathrm{~km}$ & 9.41 & 205.6 & 21.4 & 16.2 & 2.14 & 7.20 & 2.92 & 28.88 \\
\hline $25 \mathrm{~km}$ & 9.00 & 197.9 & 21.6 & 17.1 & 2.02 & 6.82 & 2.89 & 26.16 \\
\hline $50 \mathrm{~km}$ & 9.66 & 198.8 & 20.2 & 18.1 & 1.73 & 5.68 & 2.56 & 18.77 \\
\hline \multicolumn{9}{|l|}{ Summary of RCM simulations } \\
\hline RCMs average & 10.82 & 223.4 & 20.0 & 23.2 & 1.04 & 2.93 & 2.02 & 7.88 \\
\hline $12.5 \mathrm{~km}$ res. $\mathrm{RCM}$ & 11.20 & 212.5 & 18.8 & 25.9 & 0.86 & 3.00 & 1.90 & 7.96 \\
\hline $25 \mathrm{~km}$ res. RCMs & 10.54 & 215.2 & 19.8 & 22.3 & 1.08 & 3.12 & 2.04 & 9.08 \\
\hline $50 \mathrm{~km}$ res. RCMs & 11.08 & 235.0 & 20.5 & 23.9 & 1.02 & 2.60 & 2.01 & 5.97 \\
\hline \multicolumn{9}{|l|}{ RCM simulations } \\
\hline CLM & 10.84 & 208.9 & 19.2 & 22.8 & 1.06 & 3.91 & 2.09 & 13.58 \\
\hline HadRM3Q0_ERA40 & 11.83 & 239.2 & 19.6 & 20.6 & 1.19 & 3.74 & 2.11 & 12.28 \\
\hline HadRM3Q3_ERA40 & 10.05 & 169.5 & 16.5 & 18.8 & 1.00 & 2.90 & 1.70 & 6.99 \\
\hline HadRM3Q16_ERA40 & 11.40 & 226.7 & 19.1 & 21.5 & 1.08 & 3.21 & 1.98 & 9.56 \\
\hline HadRM3Q0_HadCM3 & 11.33 & 278.3 & 23.9 & 23.2 & 1.28 & 4.20 & 2.62 & 16.90 \\
\hline HadRM3Q3_HadCM3 & 10.51 & 209.0 & 19.5 & 21.6 & 1.04 & 3.01 & 2.01 & 8.56 \\
\hline HadRM3Q16_HadCM3 & 10.31 & 231.7 & 21.6 & 23.2 & 1.11 & 3.48 & 2.27 & 11.84 \\
\hline H5_ARPEGE & 7.61 & 132.7 & 16.9 & 17.4 & 1.19 & 2.83 & 1.70 & 5.67 \\
\hline H5_BCM & 12.70 & 246.6 & 18.5 & 20.5 & 1.08 & 2.51 & 1.83 & 5.27 \\
\hline H5_ECHAM5 & 11.11 & 224.7 & 19.0 & 20.5 & 1.13 & 2.91 & 1.92 & 6.54 \\
\hline RACMO2_ECHAM5 & 9.42 & 191.0 & 20.2 & 26.6 & 0.91 & 2.81 & 2.02 & 7.69 \\
\hline RACMO2_MIROC & 9.67 & 217.8 & 22.4 & 31.1 & 0.85 & 2.74 & 2.24 & 8.63 \\
\hline RACMO22E & 11.20 & 212.5 & 18.8 & 25.9 & 0.86 & 3.00 & 1.90 & 7.96 \\
\hline RCA4_CanESM2 & 10.65 & 221.5 & 20.0 & 23.9 & 1.01 & 2.63 & 1.97 & 6.01 \\
\hline RCA4_CM5A-MR & 11.14 & 219.4 & 19.2 & 22.7 & 1.02 & 2.53 & 1.89 & 5.46 \\
\hline RCA4_CNRM-CM5 & 12.38 & 289.2 & 22.5 & 25.0 & 1.07 & 2.77 & 2.23 & 6.94 \\
\hline RCA4_EC-EARTH & 11.11 & 249.7 & 21.7 & 26.4 & 0.95 & 2.44 & 2.11 & 5.86 \\
\hline RCA4_ERAINT & 10.20 & 208.1 & 19.9 & 23.0 & 1.03 & 2.67 & 1.97 & 6.04 \\
\hline RCA4_ESM2M & 12.08 & 275.6 & 22.2 & 26.1 & 0.99 & 2.53 & 2.17 & 6.25 \\
\hline RCA4_ESM-LR & 11.45 & 257.9 & 21.9 & 25.0 & 1.06 & 2.72 & 2.17 & 6.65 \\
\hline RCA4_HadGEM2-ES & 9.93 & 173.3 & 16.8 & 21.6 & 0.93 & 2.35 & 1.62 & 4.35 \\
\hline RCA4_MIROC5 & 10.11 & 221.2 & 21.2 & 23.0 & 1.11 & 2.83 & 2.11 & 6.67 \\
\hline RCA4_NorESM1-M & 11.76 & 233.8 & 19.2 & 21.9 & 1.03 & 2.57 & 1.89 & 5.41 \\
\hline
\end{tabular}

than at-site $D$ for the whole range of event depths. For the rest of the characteristics the area averaging effect is in general stronger for larger quantiles of the distribution (leading to lower values of characteristics). The area-average event characteristics are similar to the at-site characteristics only for the duration $(T)$ of short events and rainfall rate $(R)$ of less intense events.

To demonstrate how spatial resolution influences the areaaverage characteristics, box plots of $\mathrm{rt}_{\mathrm{m}}$ for the area-average observations are presented as a part of Fig. 3 (grey box plots in the right part of each panel). Most of the area-average characteristics decrease with increasing area. The exception is event duration $(T)$, which increases with area, and seasonal characteristics (number of heavy rainfall events and total precipitation due to these events) which are rather resolution independent. The differences are generally small (less than $10 \%$ ), with the exceptions of $R, I_{60}$, and $\mathrm{EI}_{60}$ (up to $20 \%$ ).

\subsection{Simulated mean (event and seasonal) characteristics}

Figure 3 presents box plots of $\mathrm{rt}_{\mathrm{m}}$ ratios between the RCMsimulated and observed at-site rainfall event characteristics 

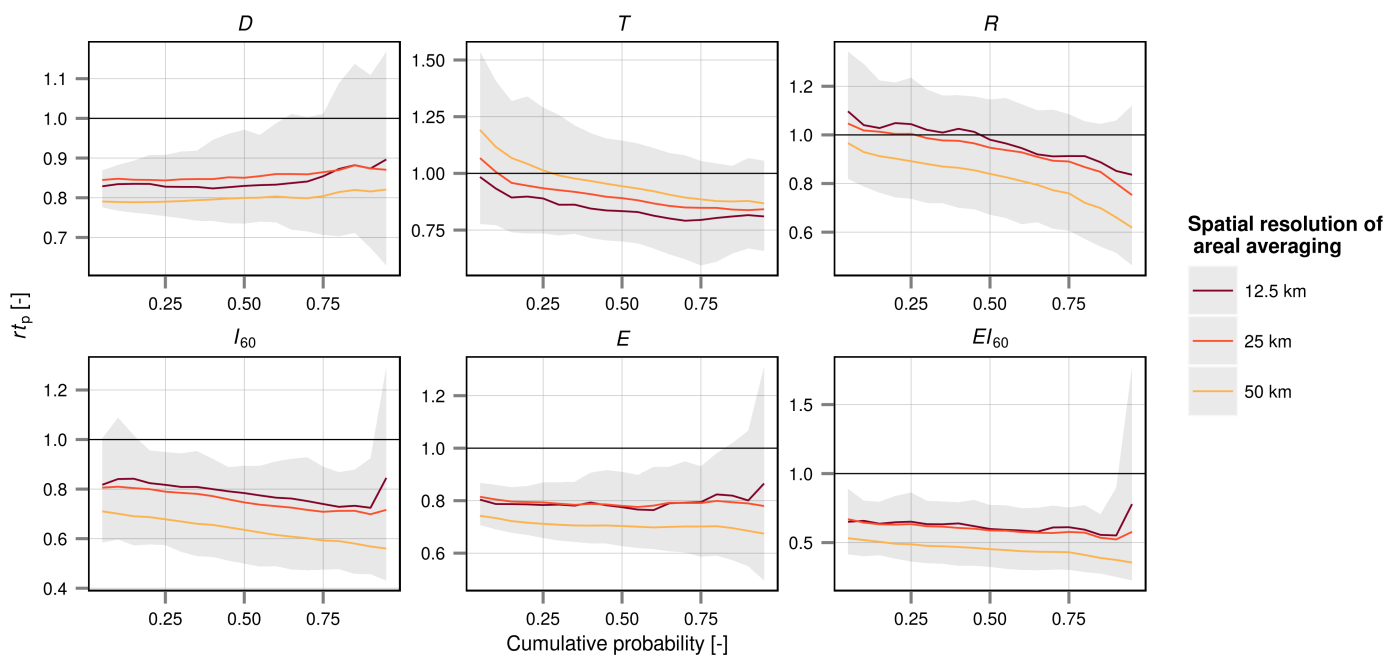

Figure 2. Quantile ratios $\mathrm{rt}_{p}$ for the distribution of the area-average and at-site rainfall event characteristics $\left(D, T, R, I_{60}, E, \mathrm{EI}_{60}\right)$. For each spatial resolution $(12.5,25,50 \mathrm{~km})$, the average from all neighbourhoods is indicated by a solid line. Envelopes of $\mathrm{rt}_{p}$ for all neighbourhoods (grey areas) represent the maximum range between the 5th and 95th quantiles for the three considered spatial resolutions.

for the validation period (1981-2000) as derived for grid boxes over the study area.

In the RCM simulations, the event depths $(D)$ correspond generally well with the area-average observations (20\% smaller on average compared to at-site observations). Event duration $(T)$ is longer for most of the RCM simulations than for at-site observations (on average by $18 \%$ ). That is in contrast with the area-average observations, for which the event duration $(T)$ is shorter than for at-site observations. Because event depths $(D)$ for the RCM simulations are smaller than for at-site observations and event durations $(T)$ are longer in general, event mean rainfall rates $(R)$ are significantly lower compared to the at-site characteristics. Other event characteristics are also significantly lower for RCM simulations compared to the observed characteristics.

The number of heavy events per season $\left(N_{\mathrm{se}}\right)$ is in general higher in the RCM simulations (ca. $16 \%$ on average, i.e. less than 1.5 events per season). The differences in $S_{\text {se }}$ between the RCM simulations and observations range from -33 to $+48 \%(+11 \%$ on average, i.e. $23 \mathrm{~mm}$ per season compared to the area-average observations).

Note that the differences in seasonal and event characteristics may be considerably larger for individual RCM simulations, in particular at grid boxes with high altitude. For instance $N_{\text {se }}$ and $S_{\text {se }}$ in the two HIRHAM5 simulations (H5_BCM and H5_ECHAM5) are more than three times larger than the observed characteristics at corresponding grid boxes.

The coefficient of variation $\left(\mathrm{CV}\right.$; not shown) of $\mathrm{rt}_{\mathrm{m}}$ for the RCM grid boxes (indicator of spatial variability) corresponds relatively well with that of the area-average observations for event depth ( $D$; CV about $9 \%$ on average), duration ( $T$; about $12 \%$ ), rainfall rate, maximum 60 min inten- sity, and kinetic energy $\left(R, I_{60}\right.$, and $E$, respectively; all about $10 \%$ ). The RCM-simulated spatial variability is lower compared to the area-average observations for the event rainfall erosivity index $\left(\mathrm{EI}_{60}\right)$ and significantly larger for the number of heavy events per season $\left(N_{\mathrm{se}}\right)$ and seasonal totals due to heavy events $\left(S_{\mathrm{se}}\right)$. Only for RACMO2 and RACMO22E simulations do CVs for $N_{\mathrm{se}}$ and $S_{\mathrm{se}}$ correspond well with the area-average observations.

\subsection{Quantile ratios $\left(\mathrm{rt}_{p}\right)$}

Figure 4 gives the quantile ratios $\left(\mathrm{rt}_{p}\right.$ ) for the RCM simulations and the area-average observations. For the latter, only the average value (from the $12.5,25$, and $50 \mathrm{~km}$ neighbourhoods) and envelope representing the maximum 5th-95th quantile range for all neighbourhoods are shown (for details, see Sect. 4.1 and Fig. 2).

The correspondence between simulated and area-average event depths $(D)$ is best for events with large $D$. For most of the RCA4 runs, the quantile ratio $\mathrm{rt}_{p}$ depends only slightly on event depth $(D)$. That is also the case for area-average observations.

For the longest events, the RCM-simulated event duration $(T)$ corresponds relatively well with the area-average observations. However, shortest durations $(T)$ are greatly overestimated (2.3 times in the RCM simulations on average compared to the area-average characteristics). Only the event duration $(T)$ in H5_ARPEGE matches that of the area-average observations for the whole range of event durations.

The difference between RCM-simulated and area-average rainfall rate $(R)$ grows with increasing quantile. Stronger underestimation of largest rainfall rates $(R)$ is related to significant overestimation of shortest durations $(T)$. Moreover, underestimation of the maximum $60 \mathrm{~min}$ intensities $\left(I_{60}\right)$ is 

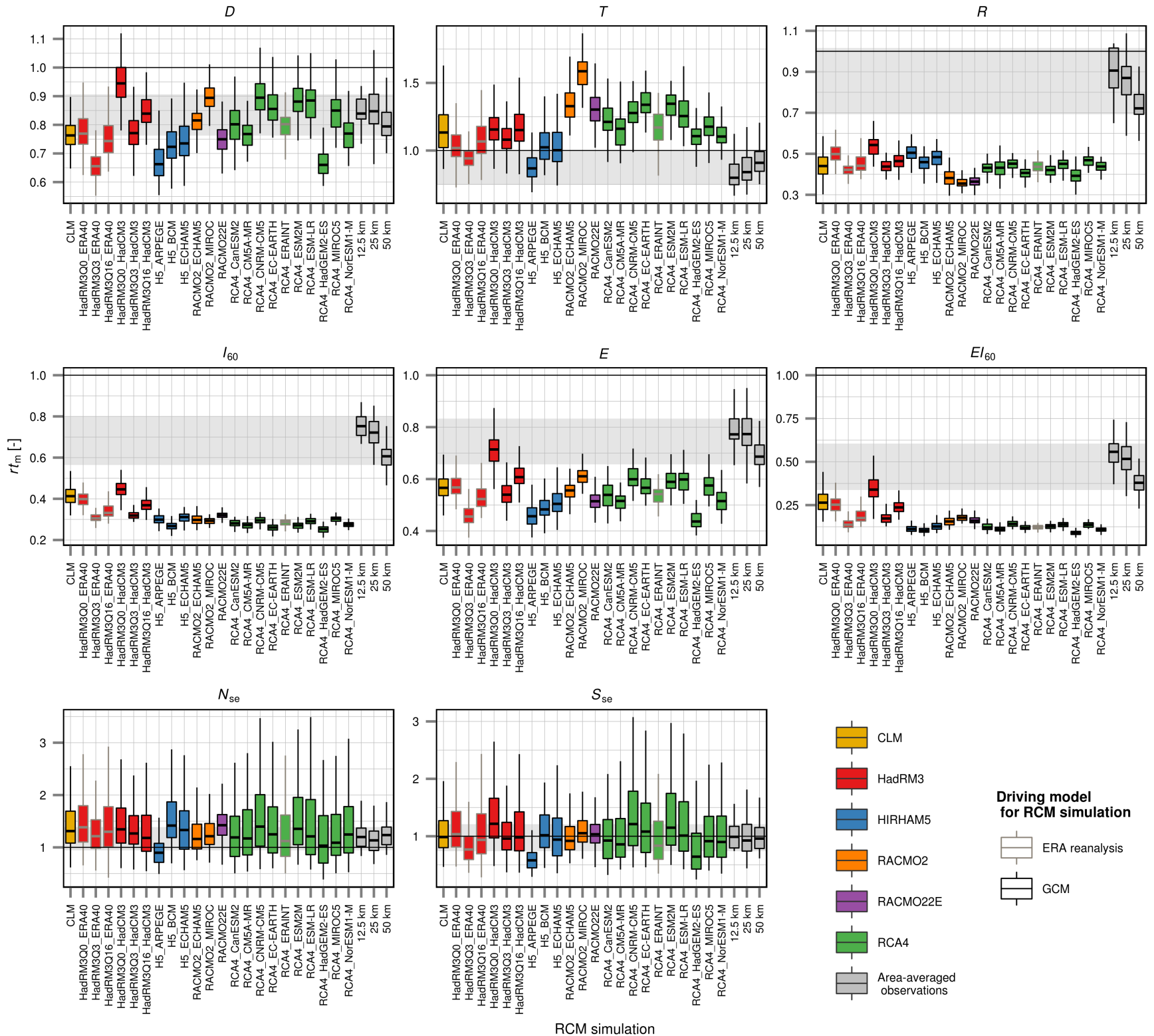

Figure 3. Ratios $\mathrm{rt}_{\mathrm{m}}$ between areal (grid box or neighbourhood) and station average of mean (event and seasonal) characteristics for each RCM simulation and area-average observations (grey box plots in the right part of each panel). Each box plot corresponds to values for all grid boxes (neighbourhoods) over the Czech Republic. Grey areas indicate the range between the minimum 25th and maximum 75 th quantiles of $\mathrm{rt}_{\mathrm{m}}$ for observed data from all neighbourhoods.

greater for larger values for most of the RCM simulations. The event rainfall energy $(E)$ as well as the event rainfall erosivity index $\left(\mathrm{EI}_{60}\right)$ are considerably underestimated.

\subsection{Histogram ratios $\left(\mathrm{rt}_{\mathrm{f}}\right)$}

Differences in distributions of rainfall event characteristics between the RCM simulations and observations are characterized by histogram ratio $\mathrm{rt}_{\mathrm{f}}$ (Fig. 5).

Considerably higher numbers of events with smaller depths $(D)$ in the RCM simulations compared to the at- site observations are expected, partly due to the definition of a rainfall event (minimum values of $D$ in the RCM simulations are between 7 and $11.5 \mathrm{~mm}$ ). The proportion of events with depths $(D)$ smaller than $13 \mathrm{~mm}$ is $22-29 \%$ for area-average observations and $15-54 \%$ for the ensemble of RCM simulations. Extreme heavy events (with depths exceeding $250 \mathrm{~mm}$ ), which rarely occur at some stations, are not present in most of the RCM simulations (exceptions being for all HIRHAM5 runs, HadRM3Q16 driven by ERA-40, and HadRM3 driven by HadCM3). 

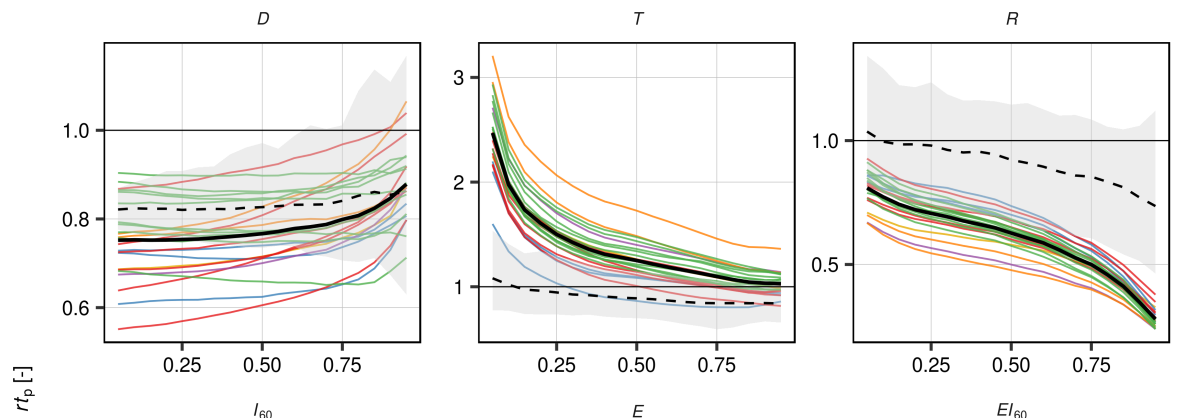

\section{Group of}

RCM simulations

CLM

$\stackrel{2}{ \pm}$
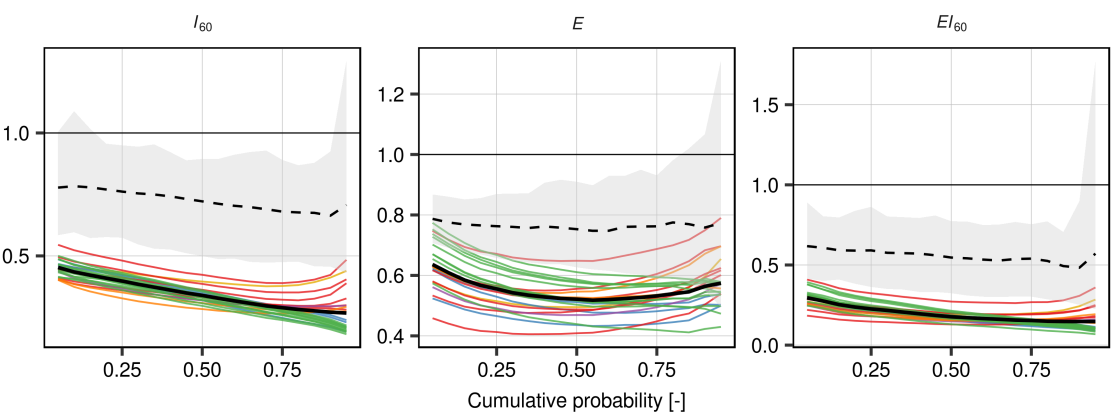

- HadRM3

- HIRHAM5

- RACMO2

- RACMO22E

RCA4

Figure 4. Area-average quantile ratios $\mathrm{rt}_{p}$ for the event characteristics derived from RCM simulations. Bold black line shows average from all RCM simulations. Grey area corresponds to the $90 \%$ envelope of the quantile ratios for the area-average observations, and broken line indicates the areal average.

(a)
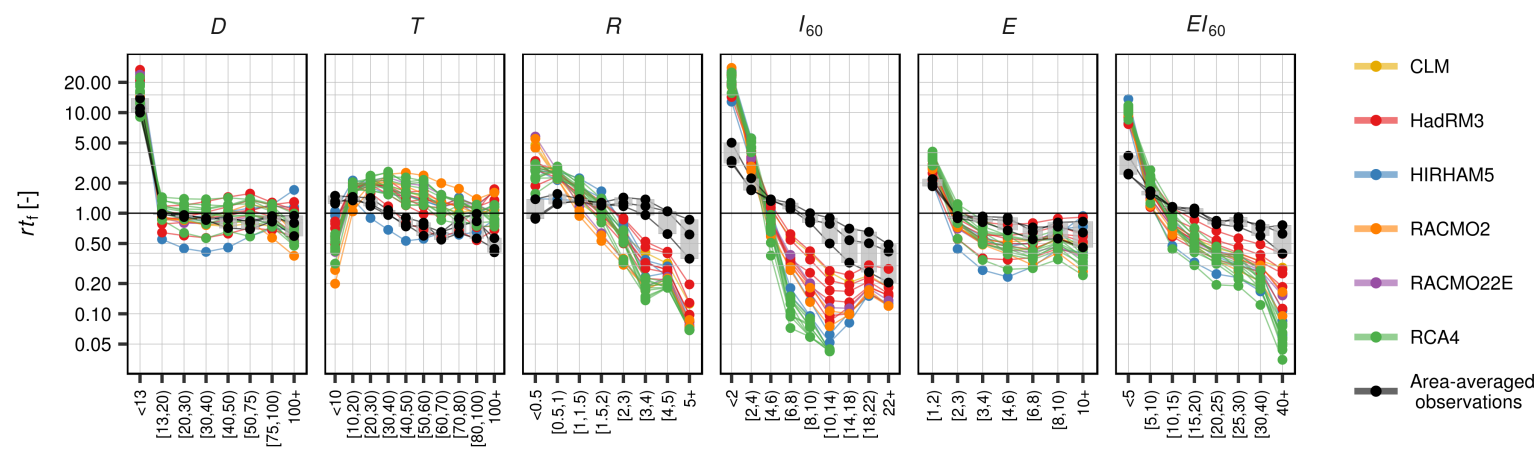

(b)

Bin of values
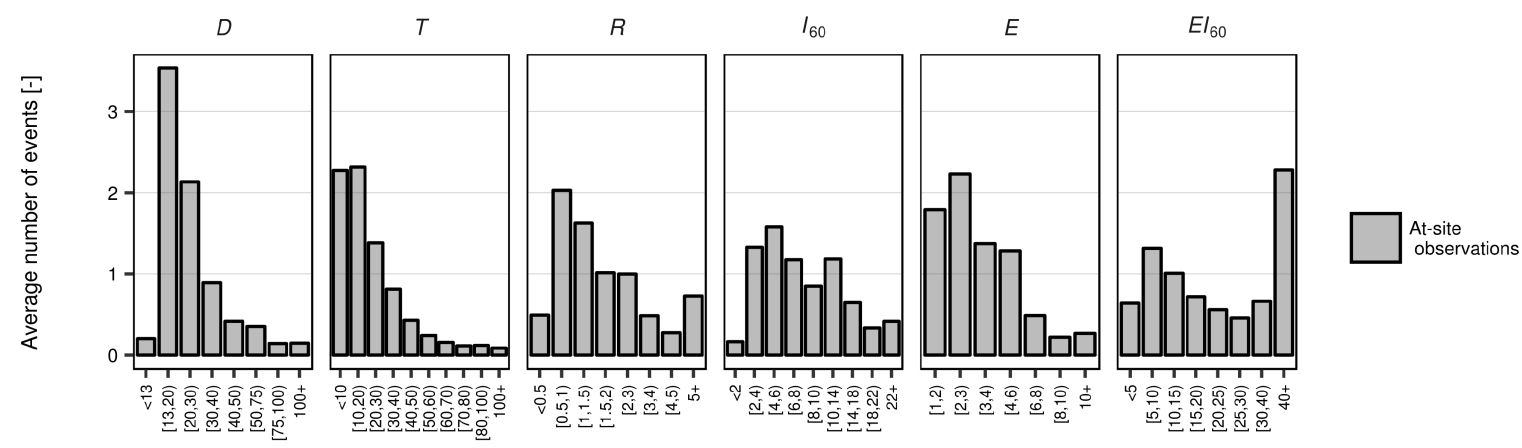

Figure 5. (a) Histogram ratios $\mathrm{rt}_{\mathrm{f}}$ between areal and station average of frequencies of corresponding bins of the histograms of rainfall event characteristics. Frequencies of bins are averaged per individual season and grid box for the RCM simulations (or neighbourhoods for areaaverage observations). Grey bars highlight ranges between the 12.5, 25, and $50 \mathrm{~km}$ area-average observations (black dots). (b) Histograms of the number of at-site events averaged per individual season and individual station. Units of characteristics defining bins of values are mm $(D), \mathrm{h}(T), \mathrm{mmh}^{-1}\left(R, I_{60}\right), \mathrm{MJ} \mathrm{ha}^{-1}(E)$, and $\mathrm{MJ} \mathrm{mmha}^{-1} \mathrm{~h}^{-1}\left(\mathrm{EI}_{60}\right)$. 
Simulated numbers of events with short duration are underestimated. Only $0.3-7.5 \%$ ( $1.6 \%$ on average) of events considered for the RCM simulations are shorter than $6 \mathrm{~h}$, while for the area-average observations it is $9-13 \%$ of events.

Events with the smallest rainfall rates $\left(R<0.5 \mathrm{mmh}^{-1}\right)$ are more frequent in the RCM simulations (8-28\% of considered events) than in the area-average observations (5$8 \%)$. On the other hand, high rainfall rates $\left(R>3 \mathrm{~mm} \mathrm{~h}^{-1}\right)$ are very rare for the RCM simulations $(0.3-4 \%$ of considered events), while for the area-average observations these represent from 8 to $15 \%$ of considered events.

Most of the simulated events (84-99\%) have maximum $60 \mathrm{~min}$ intensity $\left(I_{60}\right)$ less than $6 \mathrm{~mm} \mathrm{~h}^{-1}$, while for the areaaverage observations it is only $60-72 \%$. RCA4 simulations (50 $\mathrm{km}$ resolution) have absolute maximum values of $I_{60}$ significantly lower compared to those of other RCM simulations (only around $11 \mathrm{mmh}^{-1}$ ).

\subsection{Altitude dependence}

Figure 6 shows the altitude dependence of event characteristics for the RCM simulations and at-site observations (note that for the area-average observations the altitude dependence has not been investigated due to an uneven spatial distribution and different numbers of stations in neighbourhoods). The altitude dependence is expressed as the change of a characteristic per $100 \mathrm{~m}$ in elevation as estimated by a linear regression between altitude and the values of the rainfall event characteristics for a specific quantile. The linear regression is significant (with $p<0.05$ ) for $78 \%(68 \%)$ of the combinations of quantile and rainfall event characteristics for the observed (RCM-simulated) data.

Although the RCM simulations generally show a similar pattern of altitude dependence as that for the at-site observations regarding most characteristics (with changes between -5 and $10 \%$ per $100 \mathrm{~m}$ for all quantiles), several RCM simulations at 25 and $50 \mathrm{~km}$ resolutions show stronger altitude dependence compared to at-site observations for high (event depth, duration, rainfall energy, and rainfall erosivity index) or low (rainfall rate and maximum 60 min intensity) quantiles of rainfall event characteristics. Two simulations with the highest horizontal resolution (RACMO22E and CLM) show different behaviour for greatest event depths $(D)$ compared to those of other RCM simulations and at-site observations inasmuch as large $D$ does not increase with altitude. These differences are nevertheless less than $5 \%$.

Number of heavy events per season $\left(N_{\mathrm{se}}\right)$ and seasonal totals due to heavy events $\left(S_{\mathrm{se}}\right)$ strongly depend on altitude in the RCM simulations (not shown in Fig. 6). Simulated $N_{\text {se }}$ increase with altitude, with a slope coefficient $\beta 1.8-$ 7.7 times greater than those for at-site observations. A similar situation is found for $S_{\mathrm{se}}$, with $\beta$ 1.1-5.9 times greater. These steeper slope coefficients $\beta$ make altitude dependence of seasonal characteristics unrealistic compared to at-site ob- servations for a large part of the RCM simulations. Only two RCM simulations with the higher spatial resolution (CLM with 11.7 and $13.9 \%$ per $100 \mathrm{~m}$, and RACMO22E with 15 and $21 \%$ per $100 \mathrm{~m}$ ) represent the altitude dependence of $N_{\mathrm{se}}$ and $S_{\mathrm{se}}$ for the Czech Republic adequately (increases for atsite observations are 8.4 and $13.4 \%$ per $100 \mathrm{~m}$, respectively).

\section{Discussion}

\subsection{Definition and characteristics of rainfall events}

Heavy rainfall event characteristics were assessed in an ensemble of 23 RCM simulations. Events were identified while considering $6 \mathrm{~h}$ minimum inter-event time (MIT), $0.1 \mathrm{mmh}^{-1}$ fixed wet-hour threshold, and minimum total event depth derived for each RCM simulation as event depth with the same exceedance probability as for the $12.7 \mathrm{~mm}$ depth in the observed at-site rainfall events $(15 \%)$.

While the same $6 \mathrm{~h}$ MIT was used here for the definition of events in the observed and simulated data in order to provide comparable event characteristics and to be consistent with other studies (e.g. Agnese et al., 2006; Murakami, 2006; Fiener et al., 2013; Hanel et al., 2016) and methods (e.g. the USLE), the optimal MIT estimated by Hanel and Máca (2014) for the Czech Republic was considerably larger (426-2055 min, 763 min on average). Larger values of optimal MIT had been reported also by Dunkerley (2008b). The evaluation of the optimal MIT for the RCM simulations led to average MIT varying from $7 \mathrm{~h}$ (RCA4_NorESM1-M) to $27 \mathrm{~h}$ (HadRM3Q3_HadCM3), with an average value of $\approx 13 \mathrm{~h}$ for an ensemble of RCMs. Also the optimal MIT varied considerably among the grid boxes for each RCM simulation.

\subsection{Effect of areal averaging}

Estimates of the effect of areal averaging are influenced by several sources of uncertainties (Svensson and Jones, 2010), in particular by spatial variability and coverage of rain gauges. Because it is obvious that a sufficient number of stations must be available in order to provide a reliable estimate of the areal-averaging effect, we assessed the effect of the number of stations considered in the areal averaging on the estimated $\mathrm{rt}_{\mathrm{m}}$ ratio using a dense rain gauge network for Prague ( 22 stations, $500 \mathrm{~km}^{2}$ ). The assessment was based on repetitive estimation of $\mathrm{rt}_{\mathrm{m}}$ from resampled data with the number of stations used for areal averaging ranging from 2 to 22 .

The number of stations included into the calculation of the areal average influenced most of the estimated event characteristics. Mean event depths $(D)$ were least affected by the number of stations compared to other characteristics (with $\mathrm{rt}_{\mathrm{m}}$ decreasing with the number of stations from -12 to $-15 \%$ of the at-site value). Event duration $(T)$ was slightly increasing with the number of stations involved (from -5.6 to $4.3 \%$ ). Behaviour of $D$ and $T$ was reflected in the event 

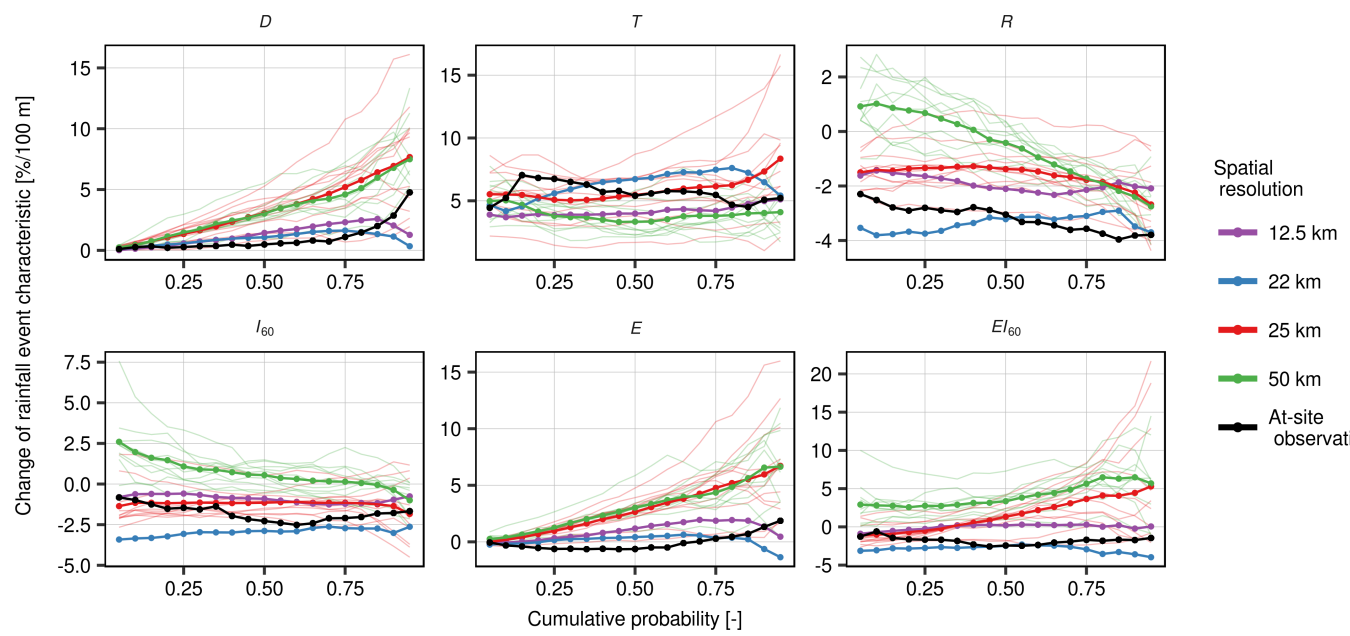

$\rightarrow 25 \mathrm{~km}$

$=50 \mathrm{~km}$

At-site

Figure 6. Dependence of rainfall event characteristics on altitude. Dependence is expressed by the change of characteristic per $100 \mathrm{~m}$ in elevation for the corresponding probability from the empirical distribution function of the event characteristics. Spatial resolution of the RCM simulations is indicated by colour (lines with points show RCM simulations average).

mean rainfall rate $(R)$, which was continually decreasing with the rising number of stations from -17 to $-39 \%$. As a consequence, the ratios for maximum 60 min intensity $\left(I_{60}\right.$; -17 to $-33 \%)$, event rainfall energy $(E ;-18$ to $-26 \%)$, and event rainfall erosivity index $\left(\mathrm{EI}_{60} ;-36\right.$ to $\left.-59 \%\right)$ were decreasing with the number of stations as well. The largest differences in ratios were observed between areal averages estimated from a small number of stations (typically fewer than 6). This finding is in agreement with Allen and DeGaetano (2005), who reported that areal reduction factors are not substantially influenced by the number of stations involved when derived from 10 or more stations. Observed area-average rainfall event characteristics for the study area (the Czech Republic) can therefore be partly affected by insufficient number of stations for resolutions finer than $50 \mathrm{~km}$ (below three stations per neighbourhood).

Several conclusions can be drawn from the comparison of area-average and at-site characteristics in general:

- More heavy rainfall events are identified in area-average observations while the area-average seasonal total precipitation due to heavy events corresponds well with that from the at-site observations.

- Area-average event characteristic values are on average lower than are those for at-site observed characteristics, except that area-average event duration is longer for the shortest events and rainfall rate is comparable for events with low rates.

- For most of the rainfall event characteristics, the difference between the area-average and at-site observations grows with increasing non-exceedance probability (the exception being event depth, for which the difference is comparable across the whole distribution).
These findings complement other studies using areal reduction factors that point out larger differences between area-average and at-site rainfall maxima for longer return periods (e.g. Skaugen, 1997; Asquith and Famiglietti, 2000; Allen and DeGaetano, 2005).

- Considerably fewer events with high maximum $60 \mathrm{~min}$ rainfall intensity $\left(I_{60}\right)$ and more events with low $I_{60}$ occur in area-average observations than in at-site observations.

- The effect of areal averaging (lower values of characteristics with larger area, except for event duration) is generally in agreement with the review published by Svensson and Jones (2010) and the analysis of Eggert et al. (2015), who have shown (for radar data) a more pronounced decrease for more extreme convective precipitation intensity with coarser spatial and larger temporal resolution. However, the estimated areal-averaging effect was not much different for the considered area sizes, and especially with respect to its great spatial variability. This might be a consequence of a small number of stations being available for estimation at finer spatial scales.

\subsection{RCM-simulated rainfall event characteristics}

Differences between the RCM-simulated and at-site observed characteristics are in general considerably larger than are those between the at-site and area-average observations, i.e. these differences are dominated by the RCMs' bias rather than the areal-averaging effect.

Although the RCM-simulated number of heavy events and seasonal total precipitation due to heavy events averaged across the Czech Republic correspond relatively well 
with the area-average observations (they are only slightly larger), large differences between individual grid boxes may be found (especially in areas with complex orography). Generally good simulation of extremes (mean annual maxima, 20 -year return values) in total precipitation amounts (from both convective and stratiform daily precipitation data together) was reported earlier for the Czech Republic by Kyselý et al. (2016). On the other hand, Hanel and Buishand (2012) found larger negative bias in daily precipitation extremes for an ensemble of RCM simulations from the ENSEMBLES project in summer (by as much as $17 \%$ ), while the bias was significantly lower in spring and autumn. Hence, including May and September into rainfall data might reduce the bias, which is smaller in our study considering depths of individual heavy rainfall events.

Recent studies considering different spatial resolutions of RCM simulations suggest that hourly precipitation characteristics of extreme events are represented better in RCMs with higher spatial resolution (e.g. Ban et al., 2014; Chan et al., 2014; Kendon et al., 2014). The better representation of hourly extremes is mainly due to the convection-resolving approach because by increasing spatial resolution to approach the convection-permitting scale (about $4 \mathrm{~km}$; Prein et al., 2015) it is possible to switch off most of the convection parameterizations (Fosser et al., 2015). All RCM simulations analysed in this paper rely on convection parameterization schemes, and the differences between RCM simulations conducted at different spatial resolutions are small and not systematic. Therefore, characteristics of rainfall events for the RCM simulations with $50 \mathrm{~km}$ resolution (RCA4) are not much different from those for other RCM simulations. Exception is the highest maximum 60 min rainfall intensity during an event $\left(I_{60}\right)$, which is underestimated more in RCA4 simulations compared to that from other RCMs. This is a consequence of an insufficient resolution for simulating subdaily extremes as suggested by Sunyer et al. (2017), who concluded that the $50 \mathrm{~km}$ spatial resolution is not sufficient to reproduce hourly extreme precipitation even though the performance of the RCMs considering daily extremes seems not to depend on the spatial resolution.

The RCM-simulated maximum 60 min rainfall intensities $\left(I_{60}\right)$ as well as the number of events with large rainfall rate $(R)$ are significantly lower than for the observed data. This may be explained by deficiencies in convective parameterization, as suggested by Kendon et al. (2012) or Kyselý et al. (2016).

Overestimation of event duration $(T)$ is a consequence of the well-known tendency of RCMs to produce too much persistent light rain and underestimate the number of dry days (e.g. Fowler et al., 2007; Boberg et al., 2009; Kendon et al., 2012). This strongly impacts especially events with the shortest durations $(T)$, which are severely overestimated in the RCM simulations. Large overestimation of short durations $(T)$ then causes pronounced underestimation of larger rainfall rates $(R)$. Fosser et al. (2015) reported the same is- sue of too-long events also for an RCM with higher resolution and most of the convective parameterizations turned off (COSMO-CLM, $2.8 \mathrm{~km}$ resolution).

It should be noted that when event duration $(T)$ is corrected (i.e. the events are proportionally shortened according to quantile ratio $\mathrm{rt}_{p}$ of event durations so that they have the same number of intervals but these intervals are shorter than $1 \mathrm{~h}$ ), mean rainfall rate $(R)$ increases to values that are well comparable with the area-average observations. For instance, correcting the event durations $(T)$ in the RACMO2_ECHAM5 simulation (corresponding best with the area-average event depths) results in an $80 \%$ increase in mean $R$ (mean characteristics are shown in Table 2). Shortening an event also increases the maximum $60 \mathrm{~min}$ intensity during an event $\left(I_{60}\right.$; by about $\left.50 \%\right)$, event rainfall energy $(E$; by $10 \%)$, and erosivity index $\left(\mathrm{EI}_{60}\right.$; by $\left.65 \%\right)$, even though these values are still slightly below the area-average observations (ratios $\mathrm{rt}_{\mathrm{m}}$ in Fig. 3 for corrected mean $I_{60}, E$, and $\mathrm{EI}_{60}$ would then be $0.46,0.61$, and 0.26 , respectively). Another option for increasing the simulated event rainfall rates is increasing the dry-hour threshold. This would result in shorter event lengths, larger rainfall rates but also smaller event depths (which are represented relatively well). In addition, the same would apply to observed data and it is not clear how this would influence the resulting bias.

Most analysed characteristics in most of the RCM simulations show a pattern of altitude dependence similar to that for the at-site observations, and the differences in strength of the altitude dependence for different quantiles of rainfall event characteristics are in general small (largest differences compared to at-site observations appear for simulations with the coarse $50 \mathrm{~km}$ resolution). The number of heavy events per season and seasonal total precipitation due to heavy events increase with altitude, and this dependence is captured better by RCM simulations with the higher spatial resolution. This could be expected due to better representation of orography as indicated by Rauscher et al. (2010) or Prein et al. (2016).

RCM simulations driven by reanalysis do not in general show better results in simulating individual rainfall events compared to the GCM-driven RCMs. That is in agreement with Hanel and Buishand (2010), who indicated that bias is largely due to the precipitation parameterization rather than the driving boundary conditions. Although HadRM3 runs driven by the ERA-40 reanalysis have event durations $(T)$ considerably shorter than the GCM-driven simulations (i.e. they show greater similarity with observations), values for event depths $(D)$ as well as other characteristics are generally lower in the ERA-40-driven simulations. As a result, the distribution functions of the other event characteristics appear similar for the simulations driven by ERA-40 as for those driven by GCMs, with larger differences occurring mostly between the perturbed and unperturbed runs. RCA4 driven by ERA-Interim reanalysis remains approximately in the middle of the range of all RCA4 runs for all event characteristics and all assessed ratios. That is in line with the inter- 
comparison of RCA4 simulations according to monthly precipitation amounts as reported by Strandberg et al. (2014).

The results and discussion presented so far were focused on the assessment of RCM performance in simulating individual rainfall events over a relatively small domain - the Czech Republic. It should be noted that at present there is no available data set allowing for assessment of RCM performance at hourly timescale over substantially larger domains or even whole Europe. However, although the bias in the RCM simulations is known to vary regionally, a number of findings can probably be transferred to other locations. This includes in particular the results concerning the effect of area averaging on the rainfall event characteristics but also the general deficiencies in the simulated event characteristics, such as strong underestimation of event rainfall rates, maxima and erosivity indices, overestimation of event duration, and dependence of the biases on the exceedance probability of event characteristics for event duration, rainfall rate and maxima.

Large part of the presented analysis considered spatial average event characteristics, especially due to lack of observed data with sufficient spatial coverage. For future research it may be an option to use radar data, provided that sufficiently long and homogenous data exist.

The bias in temporal structure of sub-daily rainfall, revealed in this study, impairs in practice the use of simulated sub-daily rainfall in hydrological applications even after standard bias correction (e.g. quantile mapping), correcting the distribution of rainfall at sub-daily timescales. It was shown in several studies that despite the correspondence of the distribution at the corrected scale, the resulting simulated hydrological response may be severely biased even for daily data (e.g. Teng et al., 2015; Hanel et al., 2017). This effect is expected to be even more pronounced in the case of sub-daily data, since the biases are larger. Therefore, unless advanced methods allowing for correction in the temporal structure of rainfall (e.g. Mehrotra and Sharma, 2016) are considered, we discourage from application of bias correction methods for sub-daily RCM simulations and suggest applications of different approaches, e.g. delta change perturbations as presented recently by Sørup et al. (2017) having advantage of preserving the temporal structure of rainfall from the observed data.

\section{Conclusions}

This study presents a methodology for analysis of precipitation characteristics in RCM simulations from an event-based perspective. Individual rainfall events and their characteristics are important with respect to many hydrological applications and rainfall impact assessment studies. Although it is generally not expected that the current RCMs would simulate sub-daily variability and rainfall event characteristics properly (e.g. Kendon et al., 2014; Westra et al., 2014), char- acterization of the biases can be useful for studies using simulated sub-daily rainfall data and also for the development of climate models, including research concerning their parameterizations, which is still very pertinent (e.g. Grell and Freitas, 2014) despite the increasing availability of convectionpermitting RCM simulations (Prein et al., 2015). The proposed methods allow for assessment of rainfall event characteristics in observed and RCM-simulated data and can be easily applied to other regions for which sub-hourly rainfall data are available.

The results suggest that representation of individual heavy-rainfall events ( $15 \%$ events with largest event depth) in the RCM simulations suffers from several deficiencies which have been only partly discussed in previous studies dealing with precipitation characteristics and extremes. The most important findings are summarized as follows:

- Differences between RCM-simulated and at-site observed rainfall event characteristics are dominated by the biases of the climate models rather than the arealaveraging effect.

- The RCMs on average represent the number of heavy rainfall events, seasonal total precipitation due to heavy events and event depths relatively well; however, the number of heavy events as well as the corresponding seasonal totals are overestimated at higher-elevated grid boxes.

- Simulated event durations are overestimated, while the event mean rainfall rate, maximum 60 min rainfall intensity, and indicators of rainfall event erosivity are significantly underestimated.

- The underestimation is larger for larger rainfall rates and maximum $60 \mathrm{~min}$ rainfall intensities during an event.

- The largest deficiencies are found for events with short duration, which are longer in the RCM simulations compared to the area-average observations. Therefore, the numbers of events with shortest duration (below $10 \mathrm{~h}$ ) are also much lower in the RCM data. Overestimation of event durations then causes underestimation of rainfall rates and partly also of other characteristics.

- The increase in number of heavy rainfall events and seasonal total precipitation due to heavy events with altitude is considerably overestimated in all RCM simulations except those with the highest spatial resolution.

The limitations in RCM-simulated rainfall event characteristics should be taken into consideration when applying their outputs in hydrological studies and climate change assessments. 


\section{Data availability}

The RCM data used in the paper were provided on personal request and cannot be redistributed. The modelling groups should be contacted for information on data availability. The observed data are property of the Czech Hydrometeorological Institute and Pražská vodohospodářská společnost a.s. and cannot be published due to licence.

Competing interests. The authors declare that they have no conflict of interest.

Acknowledgements. The research was supported by the Czech Science Foundation (project number 14-18675S); observed data were prepared within a project supported by the Ministry of the Interior of the Czech Republic (project number VG20122015092). We thank E. Buonomo (Met Office Hadley Centre), O. B. Christensen (DMI), E. van Meijgaard (KNMI), and G. Nikulin (SMHI) for providing the sub-daily RCM data. We acknowledge the ENSEMBLES project, funded by the European Commission's Sixth Framework Programme through contract GOCE-CT-2003505539, and the World Climate Research Programme's Working Group on Regional Climate, and the Working Group on Coupled Modelling, former coordinating body of CORDEX and responsible panel for CMIP5. We also thank the climate modelling groups and institutions (listed in Table 1 of this paper) for producing and making available their model output. We thank the Czech Hydrometeorological Institute and Pražská vodohospodářská společnost a.s. for providing observed at-site data.

Edited by: J. Seibert

Reviewed by: three anonymous referees

\section{References}

Agnese, C., Bagarello, V., Corrao, C., D'Agostino, L., and D'Asaro, F.: Influence of the rainfall measurement interval on the erosivity determinations in the Mediterranean area, J. Hydrol., 329, 39-48, doi:10.1016/j.jhydrol.2006.02.002, 2006.

Alexander, L. V., Zhang, X., Peterson, T. C., Caesar, J., Gleason, B., Klein Tank, A. M. G., Haylock, M., Collins, D., Trewin, B., Rahimzadeh, F., Tagipour, A., Rupa Kumar, K., Revadekar, J., Griffiths, G., Vincent, L., Stephenson, D. B., Burn, J., Aguilar, E., Brunet, M., Taylor, M., New, M., Zhai, P., Rusticucci, M., and Vazquez-Aguirre, J. L.: Global observed changes in daily climate extremes of temperature and precipitation, J. Geophys. Res.-Atmos., 111, D05109, doi:10.1029/2005JD006290, 2006.

Allen, R. J. and DeGaetano, A. T.: Areal reduction factors for two eastern United States regions with high rain-gauge density, J. Hydrol. Eng., 10, 327-335, doi:10.1061/(ASCE)10840699(2005)10:4(327), 2005.

Asquith, W. and Famiglietti, J.: Precipitation areal-reduction factor estimation using an annual-maxima centered approach, J. Hydrol., 230, 55-69, doi:10.1016/S0022-1694(00)00170-0, 2000.
Ban, N., Schmidli, J., and Schär, C.: Evaluation of the convectionresolving regional climate modeling approach in decadelong simulations, J. Geophys. Res.-Atmos., 119, 7889-7907, doi:10.1002/2014JD021478, 2014.

Ban, N., Schmidli, J., and Schär, C.: Heavy precipitation in a changing climate: Does short-term summer precipitation increase faster?, Geophys. Res. Lett., 42, 1165-1172, doi:10.1002/2014GL062588, 2015.

Barbosa, A., Fernandes, J., and David, L.: Key issues for sustainable urban stormwater management, special issue on Stormwater in urban areas, Water Res., 46, 6787-6798, doi:10.1016/j.watres.2012.05.029, 2012.

Bartholy, J., Pongrácz, R., and Kis, A.: Projected changes of extreme precipitation using multi-model approach, Idojaras, 119, 129-142, 2015.

Berg, P. and Haerter, J.: Unexpected increase in precipitation intensity with temperature - a result of mixing of precipitation types? Atmos. Res., 119, 56-61, doi:10.1016/j.atmosres.2011.05.012, 2013.

Boberg, F., Berg, P., Thejll, P., Gutowski, W., and Christensen, J.: Improved confidence in climate change projections of precipitation evaluated using daily statistics from the PRUDENCE ensemble, Clim. Dynam., 32, 1097-1106, doi:10.1007/s00382008-0446-y, 2009.

Böhm, U., Kücken, M., Ahrens, W., Block, A., Hauffe, D., Keuler, K., Rockel, B., and Will, A.: CLM - the climate version of LM: brief description and long-term applications, COSMO Newsletter, 6, 225-235, 2006.

Brockhaus, P., Lüthi, D., and Schär, C.: Aspects of the diurnal cycle in a regional climate model, Meteorol. Z., 17, 433-443, doi:10.1127/0941-2948/2008/0316, 2008.

Brown, L. C. and Foster, G. R.: Storm erosivity using idealized intensity distributions, T. ASAE, 30, 379-386, 1987.

Chan, S. C., Kendon, E. J., Fowler, H. J., Blenkinsop, S., Roberts, N. M., and Ferro, C. A. T.: The value of high-resolution Met Office regional climate models in the simulation of multihourly precipitation extremes, J. Climate, 27, 6155-6174, doi:10.1175/JCLI-D-13-00723.1, 2014.

Christensen, O. B., Drews, M., Christensen, J. H., Dethloff, K., Ketelsen, K., Hebestadt, I., and Rinke, A.: The HIRHAM regional climate model version 5 (beta), Technical Report, no. 06-17, Danish Climate Centre, Danish Meteorological Institute, Copenhagen, Denmark, 2007

Collins, M., Booth, B., Harris, G., Murphy, J., Sexton, D., and Webb, M.: Towards quantifying uncertainty in transient climate change, Clim. Dynam., 27, 127-147, doi:10.1007/s00382-0060121-0, 2006.

Collins, M., Booth, B., Bhaskaran, B., Harris, G., Murphy, J., Sexton, D., and Webb, M.: Climate model errors, feedbacks and forcings: a comparison of perturbed physics and multi-model ensembles, Clim. Dynam., 36, 1737-1766, doi:10.1007/s00382-0100808-0, 2011.

Danandeh Mehr, A. and Kahya, E.: Grid-based performance evaluation of GCM-RCM combinations for rainfall reproduction, Theor. Appl. Climatol., doi:10.1007/s00704-016-1758-1, online first, 2016

Dee, D. P., Uppala, S. M., Simmons, A. J., Berrisford, P., Poli, P., Kobayashi, S., Andrae, U., Balmaseda, M. A., Balsamo, G., Bauer, P., Bechtold, P., Beljaars, A. C. M., van de Berg, L., Bid- 
lot, J., Bormann, N., Delsol, C., Dragani, R., Fuentes, M., Geer, A. J., Haimberger, L., Healy, S. B., Hersbach, H., Hólm, E. V., Isaksen, L., Kållberg, P., Köhler, M., Matricardi, M., McNally, A. P., Monge-Sanz, B. M., Morcrette, J.-J., Park, B.-K., Peubey, C., de Rosnay, P., Tavolato, C., Thépaut, J.-N., and Vitart, F.: The ERA-Interim reanalysis: configuration and performance of the data assimilation system, Q. J. Roy. Meteor. Soc., 137, 553-597, doi:10.1002/qj.828, 2011.

Dunkerley, D.: Intra-storm evaporation as a component of canopy interception loss in dryland shrubs: observations from Fowlers Gap, Australia, Hydrol. Process., 22, 1985-1995, doi:10.1002/hyp.6783, 2008a.

Dunkerley, D.: Identifying individual rain events from pluviograph records: a review with analysis of data from an Australian dryland site, Hydrol. Process., 22, 5024-5036, doi:10.1002/hyp.7122, 2008b.

Dunkerley, D.: Intra-event intermittency of rainfall: an analysis of the metrics of rain and no-rain periods, Hydrol. Process., 29, 3294-3305, doi:10.1002/hyp.10454, 2015.

Eggert, B., Berg, P., Haerter, J. O., Jacob, D., and Moseley, C.: Temporal and spatial scaling impacts on extreme precipitation, Atmos. Chem. Phys., 15, 5957-5971, doi:10.5194/acp-15-59572015, 2015.

Einfalt, T., Krejci, V., and Schilling, W.: Rainfall data in urban hydrology, in: Hydroinformatics tools for planning, design, operation and rehabilitation of sewer systems, edited by: Marsalek, J., Maksimovic, C., Zeman, E., and Price, R., vol. 44 of NATO ASI Ser., 129-168, Springer Netherlands, Dordrecht, the Netherlands, 1998.

Fiener, P., Neuhaus, P., and Botschek, J.: Long-term trends in rainfall erosivity - analysis of high resolution precipitation time series (1937-2007) from Western Germany, Agr. Forest Meteorol., 171-172, 115-123, doi:10.1016/j.agrformet.2012.11.011, 2013.

Fosser, G., Khodayar, S., and Berg, P.: Benefit of convection permitting climate model simulations in the representation of convective precipitation, Clim. Dynam., 44, 45-60, doi:10.1007/s00382-014-2242-1, 2015.

Fowler, H. J. and Ekström, M.: Multi-model ensemble estimates of climate change impacts on UK seasonal precipitation extremes, Int. J. Climatol., 29, 385-416, doi:10.1002/joc.1827, 2009.

Fowler, H. J., Ekström, M., Blenkinsop, S., and Smith, A. P.: Estimating change in extreme European precipitation using a multimodel ensemble, J. Geophys. Res.-Atmos., 112, D18104, doi:10.1029/2007JD008619, 2007.

Gaál, L., Molnar, P., and Szolgay, J.: Selection of intense rainfall events based on intensity thresholds and lightning data in Switzerland, Hydrol. Earth Syst. Sci., 18, 1561-1573, doi:10.5194/hess-18-1561-2014, 2014.

Giulianelli, M., Miserocchi, F., Napolitano, F., and Russo, F.: Influence of space-time rainfall variability on urban runoff, Proceedings of the 17th IASTED International Conference on Modelling and Simulation, 24-26 May 2006, Montreal, QC, Canada, 546551, 2006.

Gregersen, I. B., Sørup, H. J. D., Madsen, H., Rosbjerg, D., Mikkelsen, P. S., and Arnbjerg-Nielsen, K.: Assessing future climatic changes of rainfall extremes at small spatio-temporal scales, Climatic Change, 118, 783-797, doi:10.1007/s10584012-0669-0, 2013.
Grell, G. A. and Freitas, S. R.: A scale and aerosol aware stochastic convective parameterization for weather and air quality modeling, Atmos. Chem. Phys., 14, 5233-5250, doi:10.5194/acp-145233-2014, 2014.

Hanel, M. and Buishand, T. A.: On the value of hourly precipitation extremes in regional climate model simulations, J. Hydrol., 393, 265-273, doi:10.1016/j.jhydrol.2010.08.024, 2010.

Hanel, M. and Buishand, T. A.: Analysis of precipitation extremes in an ensemble of transient regional climate model simulations for the Rhine basin, Clim. Dynam., 36, 1135-1153, doi:10.1007/s00382-010-0822-2, 2011.

Hanel, M. and Buishand, T. A.: Multi-model analysis of RCM simulated 1-day to 30-day seasonal precipitation extremes in the Czech Republic, J. Hydrol., 412-413, 141-150, doi:10.1016/j.jhydrol.2011.02.007, 2012.

Hanel, M. and Máca, P.: Spatial variability and interdependence of rain event characteristics in the Czech Republic, Hydrol. Process., 28, 2929-2944, doi:10.1002/hyp.9845, 2014.

Hanel, M., Pavlásková, A., and Kyselý, J.: Trends in characteristics of sub-daily heavy precipitation and rainfall erosivity in the Czech Republic, Int. J. Climatol., 36, 1833-1845, doi:10.1002/joc.4463, 2016.

Hanel, M., Kožín, R., Heřmanovský, M., and Roub, R.: An R package for assessment of statistical downscaling methods for hydrological climate change impact studies, Environ. Modell. Softw., in review, 2017.

Haylock, M. R., Hofstra, N., Klein Tank, A. M. G., Klok, E. J., Jones, P. D., and New, M.: A European daily highresolution gridded data set of surface temperature and precipitation for 1950-2006, J. Geophys. Res.-Atmos., 113, D20119, doi:10.1029/2008JD010201, 2008.

He, Z., Zhao, W., Liu, H., and Chang, X.: The response of soil moisture to rainfall event size in subalpine grassland and meadows in a semi-arid mountain range: a case study in northwestern China's Qilian Mountains, J. Hydrol., 420-421, 183-190, doi:10.1016/j.jhydrol.2011.11.056, 2012.

Herrera, S., Fita, L., Fernández, J., and Gutiérrez, J. M.: Evaluation of the mean and extreme precipitation regimes from the ENSEMBLES regional climate multimodel simulations over Spain, J. Geophys. Res.-Atmos., 115, D21117, doi:10.1029/2010JD013936, 2010.

Hohenegger, C., Brockhaus, P., and Schär, C.: Towards climate simulations at cloud-resolving scales, Meteorol. Z., 17, 383-394, doi:10.1127/0941-2948/2008/0303, 2008.

Ignaccolo, M. and Michele, C. D.: A point based Eulerian definition of rain event based on statistical properties of inter drop time intervals: an application to Chilbolton data, Adv. Water Resour., 33, 933-941, doi:10.1016/j.advwatres.2010.04.002, 2010.

Jacob, D., Petersen, J., Eggert, B., Alias, A., Christensen, O., Bouwer, L., Braun, A., Colette, A., Déqué, M., Georgievski, G., Georgopoulou, E., Gobiet, A., Menut, L., Nikulin, G., Haensler, A., Hempelmann, N., Jones, C., Keuler, K., Kovats, S., Kröner, N., Kotlarski, S., Kriegsmann, A., Martin, E., van Meijgaard, E., Moseley, C., Pfeifer, S., Preuschmann, S., Radermacher, C., Radtke, K., Rechid, D., Rounsevell, M., Samuelsson, P., Somot, S., Soussana, J.-F., Teichmann, C., Valentini, R., Vautard, R., Weber, B., and Yiou, P.: EURO-CORDEX: new high-resolution climate change projections for European impact research, Reg. 
Environ. Change, 14, 563-578, doi:10.1007/s10113-013-0499-2, 2014.

Kendon, E. J., Roberts, N. M., Senior, C. A., and Roberts, M. J.: Realism of rainfall in a very high-resolution regional climate model, J. Climate, 25, 5791-5806, doi:10.1175/JCLI-D-11-00562.1, 2012

Kendon, E. J., Roberts, N. M., Fowler, H. J., Roberts, M. J., Chan, S. C., and Senior, C. A.: Heavier summer downpours with climate change revealed by weather forecast resolution model, Nat. Clim. Change, 4, 570-576, doi:10.1038/nclimate2258, 2014.

Kupiainen, M., Samuelsson, P., Jones, C., Jansson, C., Willén, U., Hansson, U., Ullerstig, A., Wang, S., and Döscher, R.: Rossby Centre regional atmospheric model, RCA4, Rossby Centre Newsletter, SMHI, Norrköping, Sweden, 2011.

Květoň, V., Zahradníček, J., and Žák, M.: Quality control and digitising of pluviographic measurements in the Czech Hydrometeorological Institute, Meteorologické zprávy, 57, 47-52, 2004.

Kyselý, J., Gaál, L., Beranová, R., and Plavcová, E.: Climate change scenarios of precipitation extremes in Central Europe from ENSEMBLES regional climate models, Theor. Appl. Climatol., 104, 529-542, doi:10.1007/s00704-010-0362-z, 2011.

Kyselý, J., Rulfová, Z., Farda, A., and Hanel, M.: Convective and stratiform precipitation characteristics in an ensemble of regional climate model simulations, Clim. Dynam., 46, 227-243, doi:10.1007/s00382-015-2580-7, 2016.

Lautenschlager, M., Keuler, K., Wunram, C., Keup-Thiel, E., Schubert, M., Will, A., Rockel, B., and Boehm, U.: Climate simulation with CLM, climate of the 20th century run no. 2, data stream 3: European region MPI-M/MaD, World Data Center for Climate (WDCC), doi:10.1594/WDCC/CLM_C20_2_D3, 2009.

Lenderink, G. and van Meijgaard, E.: Increase in hourly precipitation extremes beyond expectations from temperature changes, Nat. Geosci., 1, 511-514, doi:10.1038/ngeo262, 2008.

Madsen, H., Lawrence, D., Lang, M., Martínková, M., and Kjeldsen, T.: Review of trend analysis and climate change projections of extreme precipitation and floods in Europe, J. Hydrol., 519, 3634-3650, doi:10.1016/j.jhydrol.2014.11.003, 2014.

Martínková, M. and Hanel, M.: Evaluation of relations between extreme precipitation and temperature in observational time series from the Czech Republic, Adv. Meteorol., 2016, 2975380, doi:10.1155/2016/2975380, 2016.

Mehrotra, R. and Sharma, A.: A multivariate quantile-matching bias correction approach with auto- and cross-dependence across multiple time scales: implications for downscaling, J. Climate, 29, 3519-3539, doi:10.1175/JCLI-D-15-0356.1, 2016.

Millán, M. M.: Extreme hydrometeorological events and climate change predictions in Europe, J. Hydrol, 518, Part B, 206-224, doi:10.1016/j.jhydrol.2013.12.041, 2014.

Murakami, S.: A proposal for a new forest canopy interception mechanism: splash droplet evaporation, J. Hydrol., 319, 72-82, doi:10.1016/j.jhydrol.2005.07.002, 2006.

Peters, O. and Christensen, K.: Rain viewed as relaxational events, J. Hydrol., 328, 46-55, doi:10.1016/j.jhydrol.2005.11.045, 2006.

Prein, A. F., Langhans, W., Fosser, G., Ferrone, A., Ban, N., Goergen, K., Keller, M., Tölle, M., Gutjahr, O., Feser, F., Brisson, E., Kollet, S., Schmidli, J., van Lipzig, N. P. M., and Leung, R.: A review on regional convection-permitting climate modeling: demonstrations, prospects, and challenges, Rev. Geophys., 53, 323-361, doi:10.1002/2014RG000475, 2015.
Prein, A. F., Gobiet, A., Truhetz, H., Keuler, K., Goergen, K., Teichmann, C., Fox Maule, C., van Meijgaard, E., Déqué, M., Nikulin, G., Vautard, R., Colette, A., Kjellström, E., and Jacob, D.: Precipitation in the EURO-CORDEX $0.11^{\circ}$ and $0.44^{\circ}$ simulations: high resolution, high benefits?, Clim. Dynam., 46, 383 412, doi:10.1007/s00382-015-2589-y, 2016.

Rajczak, J., Pall, P., and Schär, C.: Projections of extreme precipitation events in regional climate simulations for Europe and the Alpine Region, J. Geophys. Res.-Atmos., 118, 3610-3626, doi:10.1002/jgrd.50297, 2013.

Ran, Q., Su, D., Li, P., and He, Z.: Experimental study of the impact of rainfall characteristics on runoff generation and soil erosion, J. Hydrol., 424-425, 99-111, doi:10.1016/j.jhydrol.2011.12.035, 2012.

Rauscher, S. A., Coppola, E., Piani, C., and Giorgi, F.: Resolution effects on regional climate model simulations of seasonal precipitation over Europe, Clim. Dynam., 35, 685-711, doi:10.1007/s00382-009-0607-7, 2010.

Restrepo-Posada, P. and Eagleson, P.: Identification of independent rainstorms, J. Hydrol., 55, 303-319, doi:10.1016/00221694(82)90136-6, 1982.

Samuelsson, P., Jones, C. G., Willén, U., Ullerstig, A., Gollvik, S., Hansson, U., Jansson, C., Kjellström, E., Nikulin, G., and Wyser, K.: The Rossby Centre regional climate model RCA3: model description and performance, Tellus A, 63, 4-23, doi:10.1111/j.1600-0870.2010.00478.x, 2011.

Schilling, W.: Rainfall data for urban hydrology: what do we need?, Atmos. Res., 27, 5-21, doi:10.1016/0169-8095(91)90003-F, 1991.

Siler, N. and Roe, G.: How will orographic precipitation respond to surface warming? An idealized thermodynamic perspective, Geophys. Res. Lett., 41, 2606-2613, doi:10.1002/2013GL059095, 2014.

Singh, V. P.: Effect of spatial and temporal variability in rainfall and watershed characteristics on stream flow hydrograph, Hydrol. Process., 11, 1649-1669, 1997.

Skaugen, T.: Classification of rainfall into small and large-scale events by statistical pattern recognition, J. Hydrol., 200, 40-57, doi:10.1016/S0022-1694(97)00003-6, 1997.

Sørup, H. J. D., Georgiadis, S., Gregersen, I. B., and ArnbjergNielsen, K.: Formulating and testing a method for perturbing precipitation time series to reflect anticipated climatic changes, Hydrol. Earth Syst. Sci., 21, 345-355, doi:10.5194/hess-21-3452017, 2017.

Stocker, T., Qin, D., Plattner, G.-K., Tignor, M., Allen, S., Boschung, J., Nauels, A., Xia, Y., Bex, V., and Midgley, P. (Eds.): Climate change 2013: the physical science basis. Contribution of working group I to the fifth assessment report of the Intergovernmental panel on climate change, Cambridge University Press, Cambridge, UK and New York, NY, USA, doi:10.1017/CBO9781107415324, 2013.

Strandberg, G., Bärring, L., Hansson, U., Jansson, C., Jones, C., Kjellström, E., Kolax, M., Kupiainen, M., Nikulin, G., Samuelsson, P., Ullerstig, A., and Wang, S.: CORDEX scenarios for Europe from the Rossby Centre regional climate model RCA4, Report Meteorology and Climatology no. 116, Swedish Meteorological and Hydrological Institute, SE 60176 Norrköping, Sweden, 2014. 
Sunyer, M. A., Luchner, J., Onof, C., Madsen, H., and ArnbjergNielsen, K.: Assessing the importance of spatio-temporal RCM resolution when estimating sub-daily extreme precipitation under current and future climate conditions, Int. J. Climatol., 37, 688705, doi:10.1002/joc.4733, 2017.

Svensson, C. and Jones, D.: Review of methods for deriving areal reduction factors, J. Flood Risk Manage., 3, 232-245, doi:10.1111/j.1753-318X.2010.01075.x, 2010.

Teng, J., Potter, N. J., Chiew, F. H. S., Zhang, L., Wang, B., Vaze, J., and Evans, J. P.: How does bias correction of regional climate model precipitation affect modelled runoff?, Hydrol. Earth Syst. Sci., 19, 711-728, doi:10.5194/hess-19-711-2015, 2015.

Tolasz, R. (Ed.): Atlas podnebí Česka (Climate atlas of Czechia), Český hydrometeorologický ústav, 1. edn., Praha, Czech Republic, 2007.

Trenberth, K. E.: Changes in precipitation with climate change, Clim. Res., 47, 123-138, doi:10.3354/cr00953, 2011.

Uppala, S. M., Kållberg, P. W., Simmons, A. J., Andrae, U., Bechtold, V. D. C., Fiorino, M., Gibson, J. K., Haseler, J., Hernandez, A., Kelly, G. A., Li, X., Onogi, K., Saarinen, S., Sokka, N., Allan, R. P., Andersson, E., Arpe, K., Balmaseda, M. A., Beljaars, A. C. M., Berg, L. V. D., Bidlot, J., Bormann, N., Caires, S., Chevallier, F., Dethof, A., Dragosavac, M., Fisher, M., Fuentes, M., Hagemann, S., Hólm, E., Hoskins, B. J., Isaksen, L., Janssen, P. A. E. M., Jenne, R., Mcnally, A. P., Mahfouf, J.-F., Morcrette, J.-J., Rayner, N. A., Saunders, R. W., Simon, P., Sterl, A., Trenberth, K. E., Untch, A., Vasiljevic, D., Viterbo, P., and Woollen, J.: The ERA-40 re-analysis, Q. J. Roy. Meteor. Soc., 131, 29613012, doi:10.1256/qj.04.176, 2005.

van der Linden, P. and Mitchell, J. F. B. (Eds.): ENSEMLES: climate change an its impacts: summary of research and results from the ENSEMBLES project, Met Office Hadley Centre, Exeter, UK, 2009. van Meijgaard, E., van Ulft, L. H., van de Berg, W. J., Bosveld, F. C., van den Hurk, B., Lenderink, G., and Siebesma, A. P.: The KNMI regional atmospheric climate model RACMO version 2.1 , Technical Report, TR 302, KNMI, De Bilt, the Netherlands, 2008.

van Meijgaard, E., van Ulft, L., Lenderink, G., de Roode, S., Wipfler, E., Boers, R., and Timmermans, R.: Refinement and application of a regional atmospheric model for climate scenario calculations of Western Europe, KvR 054/12, Programme Office Climate changes Spatial Planning, KNMI, De Bilt, the Netherlands, 2012.

Wang, X.-P., Cui, Y., Pan, Y.-X., Li, X.-R., Yu, Z., and Young, M.: Effects of rainfall characteristics on infiltration and redistribution patterns in revegetation-stabilized desert ecosystems, J. Hydrol., 358, 134-143, doi:10.1016/j.jhydrol.2008.06.002, 2008.

Westra, S., Fowler, H. J., Evans, J. P., Alexander, L. V., Berg, P., Johnson, F., Kendon, E. J., Lenderink, G., and Roberts, N. M.: Future changes to the intensity and frequency of short-duration extreme rainfall, Rev. Geophys., 52, 522-555, doi:10.1002/2014RG000464, 2014.

Willems, P. and Vrac, M.: Statistical precipitation downscaling for small-scale hydrological impact investigations of climate change, J. Hydrol., 402, 193-205, doi:10.1016/j.jhydrol.2011.02.030, 2011.

Willems, P., Arnbjerg-Nielsen, K., Olsson, J., and Nguyen, V.: Climate change impact assessment on urban rainfall extremes and urban drainage: methods and shortcomings, Atmos. Res., 103, 106-118, doi:10.1016/j.atmosres.2011.04.003, 2012.

Wischmeier, W. H. and Smith, D. D.: Predicting rainfall erosion losses: a guide to conservation planning, Agriculture handbook 537, Science and Education Administration, U.S. Department of Agriculture, Washington, D.C., USA, 1978. 